\title{
$\mathrm{Mn}^{2+}$ complexes with pyclen-based derivatives as
}

\section{contrast agents for magnetic resonance imaging:}

\section{synthesis and relaxometry characterization.}

Marie Devreux ${ }^{1,2}$, Céline Henoumont ${ }^{1}$, Fabienne Dioury ${ }^{3}$, Sébastien Boutry ${ }^{4}$, Olivier Vacher ${ }^{3}$,

Luce Vander Elst ${ }^{1}$, Marc Port ${ }^{3}$, Robert N. Muller ${ }^{1,4}$, Olivier Sandre ${ }^{2}$ and Sophie Laurent ${ }^{1,4^{*}}$.

${ }^{1}$ University of Mons, General, Organic and Biomedical Chemistry, NMR and Molecular Imaging Laboratory, 7000 Mons, Belgium

${ }^{2}$ University of Bordeaux, CNRS, Bordeaux INP, ENSCBP, Laboratory of Organic Polymer Chemistry (LCPO), 33607 Pessac, France

${ }^{3}$ Conservatoire national des arts et métiers (CNAM), GBCM Laboratory, EA 7528, 2 rue Conté, 75003 Paris, HESAM Université, France

${ }^{4}$ Center for microscopy and molecular imaging (CMMI), 8 rue Adrienne Bolland, 6041

Charleroi, Belgium

* Corresponding author: sophie.laurent@umons.ac.be 


\title{
KEYWORDS
}

MRI, Contrast agent, Manganese ions, Pyclen

\begin{abstract}
Magnetic resonance imaging (MRI) has a leading place in medicine as an imaging tool of high resolution for anatomical studies and diagnosis of diseases, in particular for soft tissues that cannot be accessible by other modalities. Many researches are thus focused on improving the images obtained with MRI. This technique has indeed poor sensitivity, which can be compensated by using a contrast agent (CA). Today, the clinically approved CAs on market are solely based on gadolinium complexes that may induce nephrogenic systemic fibrosis (NSF) for patients with kidneys failure, while more recent studies on healthy rats also showed Gd-retention in the brain. Consequently, researchers try to elaborate other types of safer MRI CA like manganese-based complexes.
\end{abstract}

In this context, the synthesis of the $\mathrm{Mn}^{2+}$ complexes of four 12-membered pyridine-containing macrocyclic ligands based on the pyclen core was accomplished and described herein. Then, the properties of these $\mathrm{Mn}(\mathrm{II})$ complexes were studied by two relaxometric methods, ${ }^{17} \mathrm{O}$ NMR spectroscopy and ${ }^{1} \mathrm{H}$ NMR dispersion profiles. The time of residence $\left(\tau_{\mathrm{M}}\right)$ and the number of water molecules $(q)$ present in the inner-sphere of coordination were determined by these two experiments. The efficacy of the pyclen-based Mn(II) complexes as MRI CAs was evaluated by proton relaxometry at a magnetic field intensity of $1.41 \mathrm{~T}$ near those of most medical MRI scanners $(1.5 \mathrm{~T})$. Both the ${ }^{17} \mathrm{O}$ NMR and the NMRD profiles indicated that the four hexadentate ligands prepared herein left one vacant coordination site to accommodate one water molecule 
rapidly exchanging, in around 6 ns. Furthermore, it has been shown that the presence of an additional amide bond formed when the paramagnetic complex is conjugated to a molecule of interest does not alter the inner-sphere of coordination of Mn which remains monohydrated. These complexes exhibit $r_{1}$ relaxivities large enough to be used as clinical MRI CAs (1.7$3.4 \mathrm{mM}^{-1} \cdot \mathrm{s}^{-1}$, at $1.41 \mathrm{~T}$ and $\left.37^{\circ} \mathrm{C}\right)$.

\section{Introduction}

Gadolinium complexes are currently the main contrast agents (CAs) authorized and used in the clinics for medical diagnosis by Magnetic Resonance Imaging (MRI). In fact, this powerful noninvasive imaging technique often requires the use of a CA to compensate its lack of sensitivity. Different classes of CAs have been developed for MRI, yet gadolinium complexes are by far the most used in the clinical field thanks to their property to decrease the water longitudinal relaxation time of protons, highlighting on the images the areas where the CA is accumulated. ${ }^{1}$ Nevertheless, some researches have demonstrated since more than a decade that the injection of gadolinium complexes to patients with kidneys failure can trigger apparition of a disease called nephrogenic systemic fibrosis (NSF). ${ }^{2-5}$ This is particularly true for linear gadolinium complexes based on acyclic ligands such as Gd-DTPA (diethylenetriamine penta acetic acid gadolinium complex) that are less thermodynamically and kinetically stable than those based on macrocyclic complexes such as Gd-DOTA (1,4,7,10-tetraazacyclododecane-1,4,7,10-tetraacetic acid gadolinium complex). Therefore, some marketed Gd-based CAs (GBCAs) are no longer recommended for these patients. ${ }^{2,3,6}$ In addition, more recent studies have shown accumulation in the brain of gadolinium CAs in subjects with normal renal function. ${ }^{7,8}$ Further investigations were carried out on rats to compare macrocyclic $\left(\right.$ Gadoteridol $\left.^{\circledR}\right)$ with linear $\left(\right.$ Gadodiamide $^{\circledR}$ ) marketed agents and to quantify the Gd-species retained in the brain. It was concluded that 
Gadoteridol $^{\circledR}$ was much less retained than Gadodiamide ${ }^{\circledR}$ and fully detected in the urines as its intact and soluble Gd-species, whereas Gadodiamide ${ }^{\circledR}$ was found mostly as insoluble species. ${ }^{9,10}$ This situation explains that scientists are much interested in finding a safer next generation of MRI CAs based on Gd-free alternatives, and one of them could be the use of manganese-based CAs. ${ }^{11,12}$ Manganese ions are essential and naturally present in the body under the high-spin form of $\mathrm{Mn}^{2+}$ or $\mathrm{Mn}^{3+}$ with 5 or 4 unpaired d-orbital electrons, respectively. The normal physiological concentration of manganese in the serum of healthy subjects is about 0.05$0.12 \mu \mathrm{g} / \mathrm{dL}(9-22 \mu \mathrm{M})^{13}$, and part of its important biological role in the organism is to act as a cofactor activating certain enzymes or as a constituent in metalloenzymes. Manganese ions also play a role in the development of the immune and nerve systems function and in the regulation of the amount of vitamins and sugar in the blood. ${ }^{13,14}$ The first use of manganese as MRI CA was an oral formulation containing liposome-encapsulated $\mathrm{MnCl}_{2}$ salt (LumenHance ${ }^{\circledR}$ ) indicated for gastrointestinal examinations. However, several studies have shown that too high doses of free manganese ions could induce a neurodegenerative disorder called manganism, a disease with symptoms similar to those of the Parkinson's disease. Despite toxicity of free $\mathrm{Mn}^{2+}$ ions, manganese enhanced MRI (MEMRI) using $\mathrm{MnCl}_{2}$ is used for preclinical studies in mice for brain $^{15}$ or lung ${ }^{16}$ model tumors. To avoid adverse effects, manganese complexes have been developed, and the second manganese-based CA approved by the Food and Drug Administration (FDA) in 1997 was manganese dipyridoxyl diphosphate (Mn-DPDP, Teslascan ${ }^{\circledR}$, Figure 1) for use as a liver specific hepatobiliary CA. ${ }^{17}$ This structure is based on a linear ligand and has low thermodynamic and kinetic stabilities with consequently a certain amount of free manganese ions released in vivo. The efficacy of the Mn-DPDP as a MRI CA is quite low because the ligand does not allow a coordination bond with one water molecule in the 
inner-sphere of metal coordination. The interest of such a candidate as CA comes therefore from the part of the released manganese ions whose relaxivity is $2.8 \mathrm{~s}^{-1} \cdot \mathrm{mM}^{-1}$ at $20 \mathrm{MHz}$ and $40^{\circ} \mathrm{C}$ in aqueous solution; as a point of comparison, the relaxivity of Gd-DOTA which is a well-known commercialized macrocyclic CA is $3.5 \mathrm{~s}^{-1} \cdot \mathrm{mM}^{-1}$ at $20 \mathrm{MHz}$ and $3.1 \mathrm{~s}^{-1} \cdot \mathrm{mM}^{-1}$ at $60 \mathrm{MHz}$ and $37^{\circ} \mathrm{C} .{ }^{18,19}$ As a result and for safety concerns (potential toxicity of released free $\mathrm{Mn}^{2+}$ ), $\mathrm{Mn}$ DPDP is no longer commercialized for clinical use, so there is still need for Gd-free alternatives, with higher thermodynamic stability and kinetic inertness in order to avoid the release of free manganese ions in vivo, and with a higher efficacy to be competitive with GBCAs. ${ }^{4,5,11,19}$ As a possibility, researchers examined if Mn-porphyrins, where the manganese cation is the center of a heme ring, can be used as MRI CAs: they found very high longitudinal and transverse relaxivities, of 9.33 and $12.0 \mathrm{~s}^{-1} \cdot \mathrm{mM}^{-1}$ at $3 \mathrm{~T}\left(20^{\circ} \mathrm{C}\right)$ respectively, thereby enabling MRI detection in vivo of Mn-labelled cells. ${ }^{20,21}$ Porphyrins exhibit multiple advantages such as being able to stabilize manganese in its higher oxidation states $\mathrm{Mn}(\mathrm{III})$ or even $\mathrm{Mn}(\mathrm{V})$, needing to add a reducing agent in the medium such as sodium dithionite $\left(\mathrm{Na}_{2} \mathrm{~S}_{2} \mathrm{O}_{4}\right)$ to insure the $\mathrm{Mn}$ (II) state. ${ }^{22}$ However, their synthesis is delicate in the perspective of scale-up production for an envisioned clinical use. Moreover, such compounds are highly light-sensitive, which is why they are intensively studied in a context of therapeutic agents for photodynamic therapy. Slightly larger ring-shaped ligands called texaphyrins complexing $\mathrm{Mn}^{2+}$ were recently proposed as bimodal CAs (MRI and photoacoustic imaging). ${ }^{23}$ On the other hand, purely inorganic Mn-based nanoparticles (NPs) like antiferromagnetic MnO or paramagnetic Mn-doped ferrocyanide NPs (Prussian blues) were also tested as potential CAs for MRI. ${ }^{24}$

In view of this effort of the community to develop macrocyclic ligands with high affinity for $\mathrm{Mn}(\mathrm{II})$ and high efficiency as MRI $\mathrm{CAs}^{25}$, this report explores the potential of four $\mathrm{Mn}$ (II) 
complexes based on the pyclen core $(3,6,9,15$-tetraazabicyclo[9.3.1]pentadeca-1(15),11,13triene) and carrying an additional site for the conjugation to a molecule of interest, for instance a chemotoxic drug or a polymeric vector. Pyclen is an interesting 12-membered macrocyclic structure that incorporates a $N$-pyridyl donor that rigidifies and pre-organizes the ligand coordinating groups (in particular rendering the 4 nitrogen atoms coplanar), an attribute that can improve the kinetic inertness of the resulting complex. Pyclen ligands have been reported recently for coordination of luminescent lanthanide cations to develop optical probes for nearinfrared imaging. ${ }^{26}$ The pyridine subunit also provides enhanced degree of lipophilicity that can promote mixed renal and hepatobiliary clearances, another interesting attribute in the context of patients with reduced kidney function. The choice of pyclen-based chelating agents was also guided by their availability as "tailor-made" synthetic chelators prepared according to a versatile and potentially up-scalable strategy practiced by us and others which consists in assembling two synthons previously "dressed" with all the final functionalities required: the donor groups to satisfy the electronic demand of the paramagnetic ion, and an additional function to allow its conjugation to a molecule of interest. ${ }^{27-31}$ Since $\mathrm{Mn}(\mathrm{II})$ complexes typically have coordination numbers of 6 or 7 , ligands for Mn(II) cannot exceed hexadenticity to allow the exchange of at least one water co-ligand in its inner-sphere that is a crucial parameter to insure interesting relaxometric properties for MRI applications. Consequently, it was necessary to cleverly functionalize the pyclen derivative in order to limit to 6 its coordination bonds with $\mathrm{Mn}^{2+}$ while providing a sufficiently high degree of coordination to preserve satisfying thermodynamic stability of the complex. 

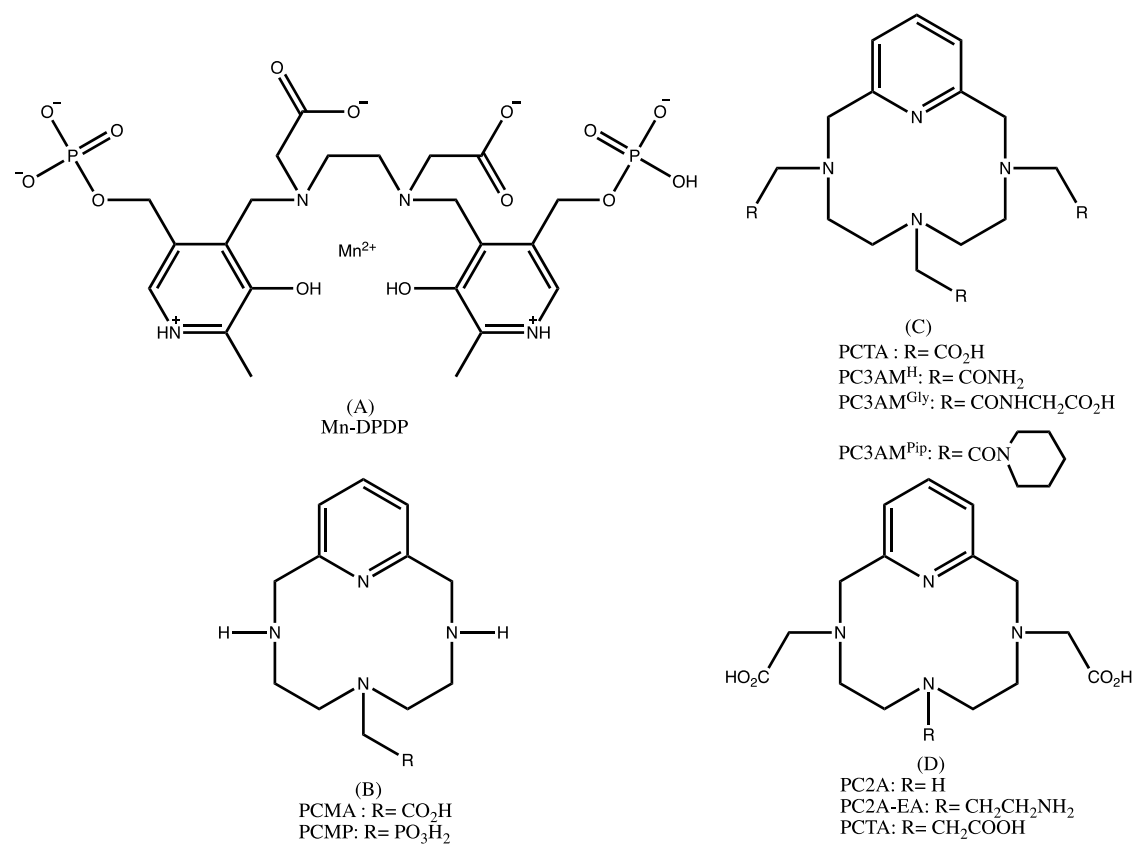

Figure 1. Structures of the ligands discussed in this work : (A) DPDP ${ }^{17}$, (B) PCMA and PCMP ${ }^{29}$

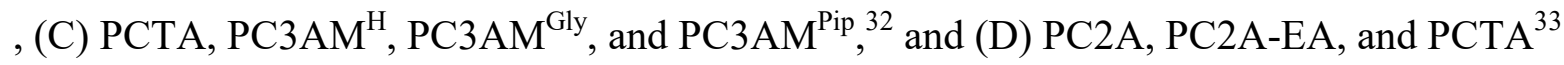

The pyclen ([12]PyN4) macrocyclic core is now recognized to form efficient chelators for the $\mathrm{Mn}^{2+}$ cation complexation, and some studies can be found on the interest of such pyridinecontaining (PC) ligands (figure 1). Drahos et al. have studied the influence on the thermodynamic stability, the kinetic inertness, the redox potential, and the ${ }^{1} \mathrm{H}$ and ${ }^{17} \mathrm{O}$ relaxation rates by modifying the nature of the coordinating group on one arm of the macrocycle. They found that the mono-functionalized pyclens PCMA and PCMP with an acetate or a methyl phosphonate pendant arm give ternary hexacoordinate $\mathrm{Mn}^{2+}$ complexes accommodated with one water co-ligand (Figure 1), both of them being rather stable. ${ }^{29}$ With a similar purpose, Garda et al. studied the influence on the proton relaxometry, the thermodynamic stability and the kinetic inertness of the presence of a primary, a secondary or a tertiary amide instead of the carboxylate functions of the PCTA which is a well know pyclen derivative. ${ }^{32}$ However, the corresponding $\mathrm{Mn}(\mathrm{II})$-complexes show quite low relaxivities, less than $2 \mathrm{~s}^{-1} \cdot \mathrm{mM}^{-1}$ at $37^{\circ} \mathrm{C}$ and $20 \mathrm{MHz}$. In a 
more recent study, Botar et al. have developed a pH-responsive CA, [Mn(PC2A-EA)] stable and inert, with a maximum relaxivity at acidic $\mathrm{pH}$ of $3.5 \mathrm{~s}^{-1} \cdot \mathrm{mM}^{-1}$ at $20 \mathrm{MHz}$ and $37^{\circ} \mathrm{C} .{ }^{33}$ All these results show that much efforts is still to be done to try increasing the efficacy of Mn-complexes as MRI contrast agents (Figure 1).

In this work, it was decided to study a series of four $\mathrm{N}_{4} \mathrm{O}_{2}$ hexadentate pyclen chelators including three structures carrying an additional function grafted onto the pyridine ring to allow conjugation to a molecule of interest (Figure 2). The "naked" complex $\mathrm{MnL}_{1} \mathrm{H}$ where $-\mathrm{H}$ designates absence of substituent in ortho position of the pyridine ring will be used as a reference to evaluate the impact of this additional subunit on the relaxometric properties of the corresponding Mn-complexes. Our previous work showed indeed that the functionalization of the carboxylate moiety into an amide bond on the pyridine arm of Gd-PCTA leads to a loss of one water molecule in the inner-sphere, giving $q=1$ instead of $q=2 .^{31}$ The syntheses are reported herein, together with the full relaxometric characterization of the corresponding $\mathrm{Mn}$ complexes in order to have a complete understanding of their efficiency as MRI CAs (Figure 2).

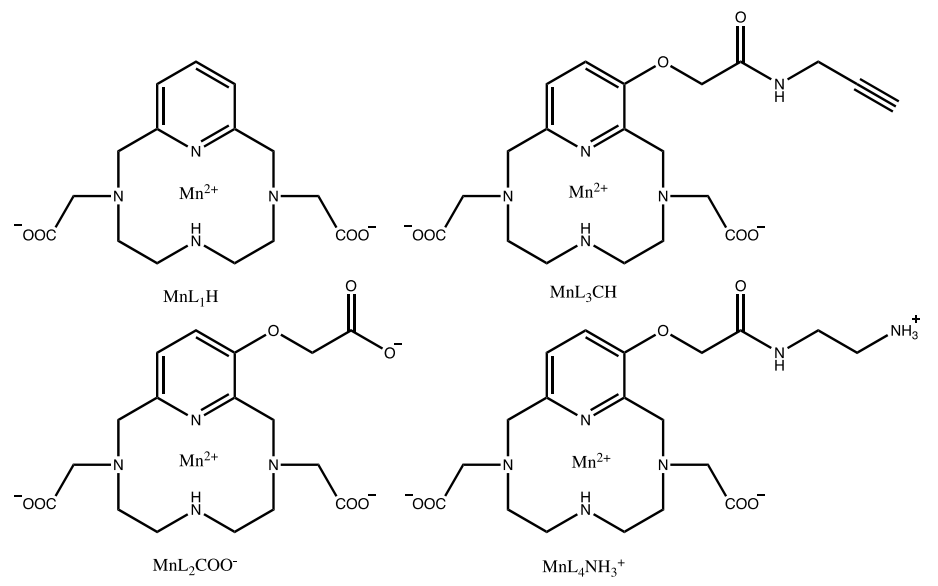

Figure 2. Structure of the four Mn-complexes synthesized and studied in this work $\mathrm{MnL}_{1} \mathrm{H}$ : $\mathrm{MnPy}\left(\mathrm{COO}^{-}\right)_{2}-\mathrm{H} ; \quad \mathrm{MnL}_{2} \mathrm{COO}^{-} \quad: \quad \mathrm{MnPy}\left(\mathrm{COO}^{-}\right)_{2}-\mathrm{OCH}_{2} \mathrm{COO}^{-} ; \quad \mathrm{MnL}_{3} \mathrm{CH}: \quad \mathrm{MnPy}\left(\mathrm{COO}^{-}\right)_{2}-$ $\mathrm{OCH}_{2} \mathrm{CONHCH}_{2} \mathrm{CCH}$ and $\mathrm{MnL}_{4} \mathrm{NH}_{3}^{+}: \mathrm{MnPy}\left(\mathrm{COO}^{-}\right)_{2}-\mathrm{OCH}_{2} \mathrm{CONH}\left(\mathrm{CH}_{2}\right)_{2} \mathrm{NH}_{3}{ }^{+}$. 


\section{Results and discussion}

\section{Synthesis of the pyclen-based $\mathrm{Mn}^{2+}$ complexes}

The synthetic route to triamine $\mathbf{5 b}$ is similar to that we described previously for the analogous compound bearing three acetate arms (Scheme 1). ${ }^{31}$ The selectively $N, N^{\prime \prime}$-protected diethylenetriamine derivative $\mathbf{2}$ was reacted in tetrahydrofuran (THF) with slight excess of both benzyl chloroformate and diisopropylethylamine (DIPEA) to afford the fully protected compound 3 in $94 \%$ yield. The next two steps, grafting of the acetate arms onto the secondary sulfonamides followed by cleavage of the $o$-nitrobenzenesulfonyl (Nosyl) protecting groups, were carried out in one-pot in warmed acetonitrile. For each of the two steps, the total consumption of both the starting materials and the monofunctionalized intermediate (i.e. $\mathbf{3}$ and 4a for the first step; $\mathbf{4 b}$ and $\mathbf{5 a}$ for the second one) was carefully monitored (TLC and/or mass spectroscopy) and led to synthon $\mathbf{5 b}$ with a yield of $85 \%$.

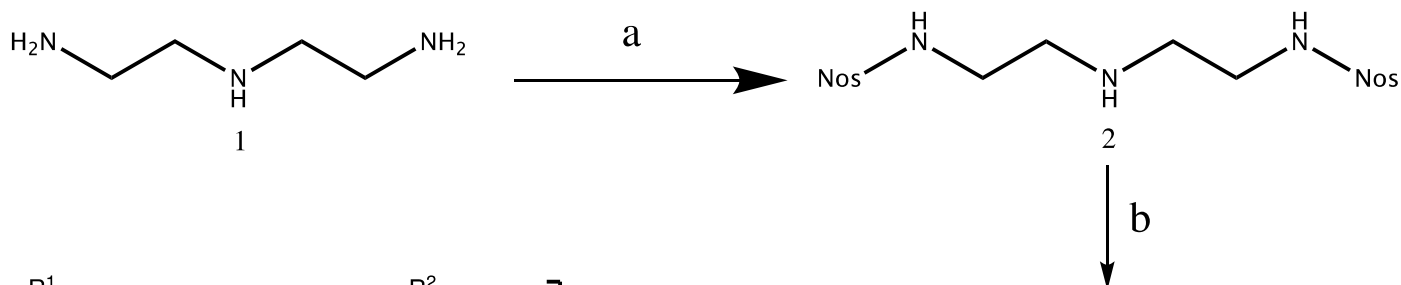

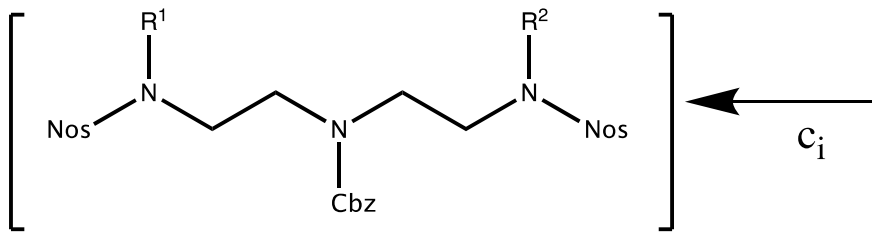

4a: $\mathrm{R}^{1}, \mathrm{R}^{2}=\mathrm{H}, \mathrm{CH}_{2} \mathrm{CO}_{2} \mathrm{tBu}$

$4 \mathrm{~b}: \mathrm{R}^{1}=\mathrm{R}^{2}=\mathrm{CH}_{2} \mathrm{CO}_{2} \mathrm{tBu}$

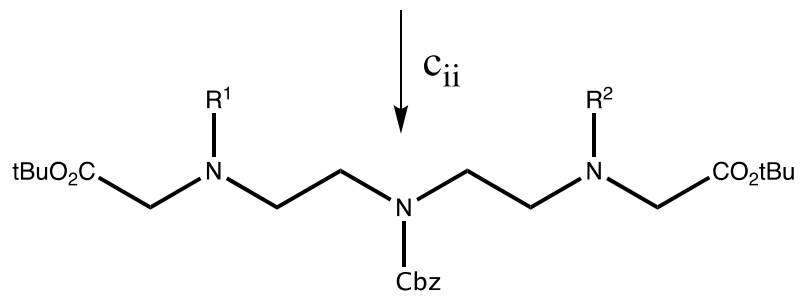

5a: $\mathrm{R}^{1}, \mathrm{R}^{2}=\mathrm{H}, \mathrm{Ns}$

$5 b: R^{1}=R^{2}=H$<smiles>O=C(OCc1ccccc1)N(CCN[Na])CCNS(=O)(=O)O</smiles>

3 
Scheme 1. Synthesis of (a) $\mathrm{NaOH}$, Nos-Cl, diethylether, THF, r.t. overnight (b) Cbz-Cl, DIPEA, THF, r.t. $1 \mathrm{~h} 30\left(\mathrm{c}_{\mathrm{i}}\right) \mathrm{BrCH}_{2} \mathrm{CO}_{2} \mathrm{tBu}, \mathrm{K}_{2} \mathrm{CO}_{3}, \mathrm{CH}_{3} \mathrm{CN}$, reflux 3-5h ( $\left.\mathrm{c}_{\mathrm{ii}}\right) \mathrm{PhSH}, \mathrm{K}_{2} \mathrm{CO}_{3}, 60^{\circ} \mathrm{C} 2-4 \mathrm{~h}$

As previously described for PCTA derivatives, the pyclen macro-ring formation was achieved by reacting the triamine $\mathbf{5 b}$ with a small excess of 2,6-dibromomethylpyridine $\mathbf{6 a}-\mathbf{b}$ under heterogeneous conditions in refluxing acetonitrile at moderate dilution $(0.01 \mathrm{M})$ with sodium carbonate as scavenger (Scheme 2). ${ }^{31}$ In such conditions, the corresponding macrocycles 7a-b were isolated in 39 and $64 \%$ yields respectively.

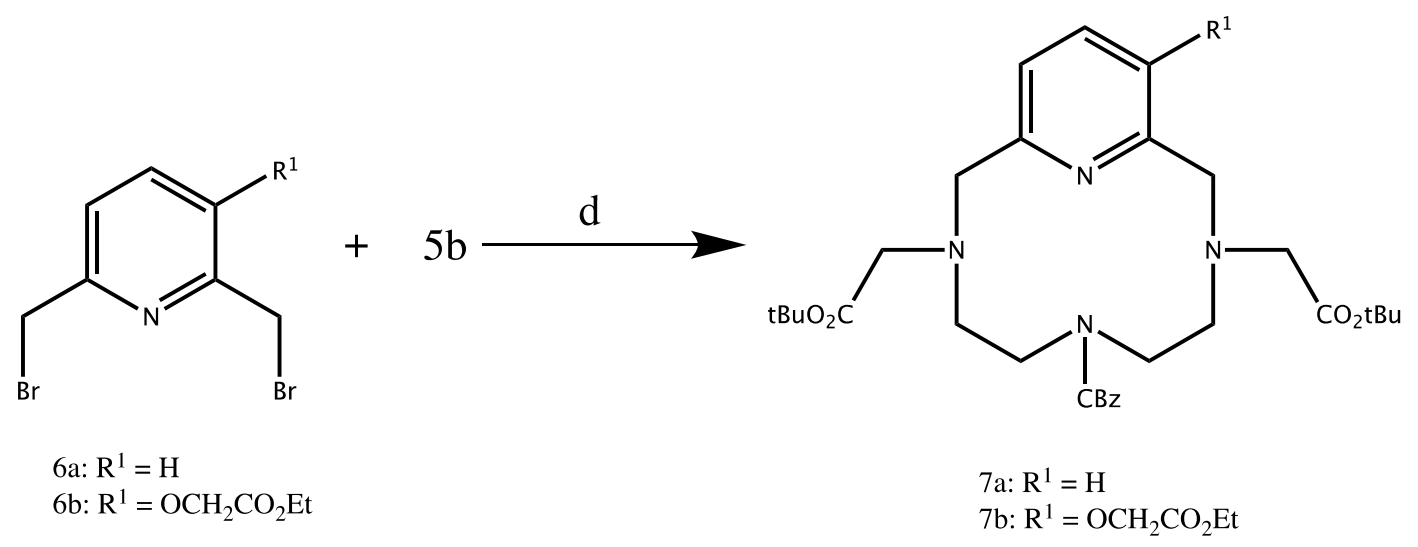

Scheme 2. Synthesis of (d) $\mathrm{Na}_{2} \mathrm{CO}_{3}, \mathrm{CH}_{3} \mathrm{CN}$, reflux

The macrocyclic pyclen skeleton built, successive step-by-step deprotections were necessary in order to allow selective grafting of different molecules of interest on the additional pendant group attached on the pyridine moiety and on the macrocycle (Scheme 3-5).

The carboxybenzyl group of compound 7a-b was smoothly removed by a pallado-catalyzed hydrogenolysis under an atmospheric pressure of $\mathrm{H}_{2}$ at room temperature and afforded compound 8a-b (Scheme 3). The reaction can be performed in $\mathrm{MeOH}$ and $\mathrm{EtOH}$ but using of $\mathrm{MeOH}$ for $\mathbf{8 b}$ can lead to transesterification. However, obtaining a mixture (if partial) of both methyl and ethyl esters does not impact the next step of saponification. The controlled removal of the ethyl ester group of compound $\mathbf{8 b}$ was then achieved by mild saponification with $\mathrm{NaOH}$ 
and provided the corresponding carboxylate 9 in $67 \%$ yield. The tert-butyl ester functions of the prochelators 8a and 9 were removed by treatment with trifluoroacetic acid and led to the pyclen-based chelating agents $\mathbf{1 0 a - b}$ that were finally complexed to $\mathrm{Mn}$ (II) by reaction with an equimolar amount of manganese dichloride tetrahydrate at controlled $\mathrm{pH}(\mathrm{ca} 5-6)$ to give the $\mathrm{Mn}^{2+}$ complexes 11a-b.

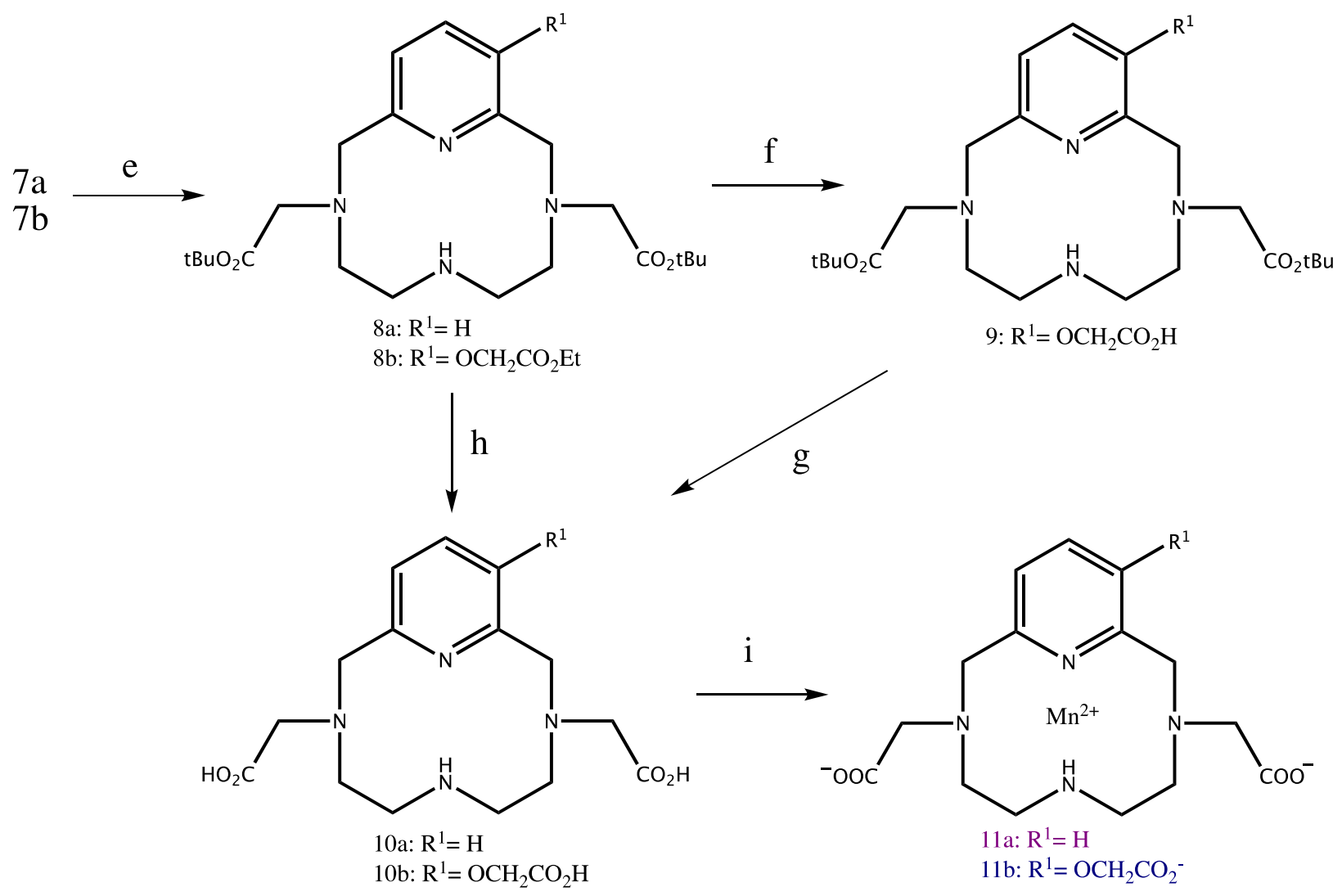

Scheme 3. Synthesis of (e) $\mathrm{Pd} / \mathrm{C}, \mathrm{EtOH}$ or $\mathrm{MeOH}, \mathrm{H}_{2}$ atm, r.t. overnight (f) $\mathrm{NaOH}$, EtOH, r.t. 7 h (g) and (h) $\mathrm{CF}_{3} \mathrm{CO}_{2} \mathrm{H}, \mathrm{CH}_{2} \mathrm{Cl}_{2}$, r.t. overnight (i) $\mathrm{MnCl}_{2} \cdot 4 \mathrm{H}_{2} \mathrm{O}, \mathrm{H}_{2} \mathrm{O}, \mathrm{pH} 5-6,40^{\circ} \mathrm{C}$ overnight. $11 \mathrm{a}$ is compound $\left(\mathrm{MnL}_{1} \mathrm{H}\right), 11 \mathrm{~b}$ is compound $\left(\mathrm{MnL}_{2} \mathrm{COO}^{-}\right)$. 
Compound 9 has an additional carboxylic acid function on the pyridine subunit to allow subsequent conjugation to an amine function of different molecules of interest (Scheme 3). As previously shown by us for a bifunctional PCTA chelator prepared to complex $\mathrm{Gd}^{3+},{ }^{31}$ the resulting amide bond can act as an additional donor group so that the overall denticity of the chelator is increased, and the coordination of water molecule as co-ligand in the inner-sphere of the paramagnetic center can be compromised which has a negative impact on the relaxivity of the chelate. Consequently, it was decided to study the impact of this additional amide bond on the relaxivity of the $\mathrm{Mn}^{2+}$ complexes.

Both compounds 14 and 17 were designed with a dual purpose: to study the influence of an additional pendant amide bond on relaxometry, and to vary the function to allow subsequent conjugation for forthcoming studies: by click chemistry with Huisgen's 1,3-cyloaddition on the alkyne end-group, or by coupling the primary amine with carboxylic acid groups (Schemes 4-5).

On the one hand, propargylamine was grafted to compound 9 using the uronium-based activating agent $\quad$ HBTU (O-(benzotriazol-1-yl)- $N, N, N^{\prime}, N^{\prime}$-tetramethyluronium hexafluorophosphate) and afforded the carbamoyl derivative $\mathbf{1 2}$ (over $90 \%$ yield) whose tertbutyl ester functions were then removed upon treatment with trifluoroacetic acid. The resulting pyclen-based chelating agent $\mathbf{1 3}$ as trifluoroacetic salt was finally complexed to $\mathrm{Mn}$ (II) as previously done for 10a-b (Scheme 4). 


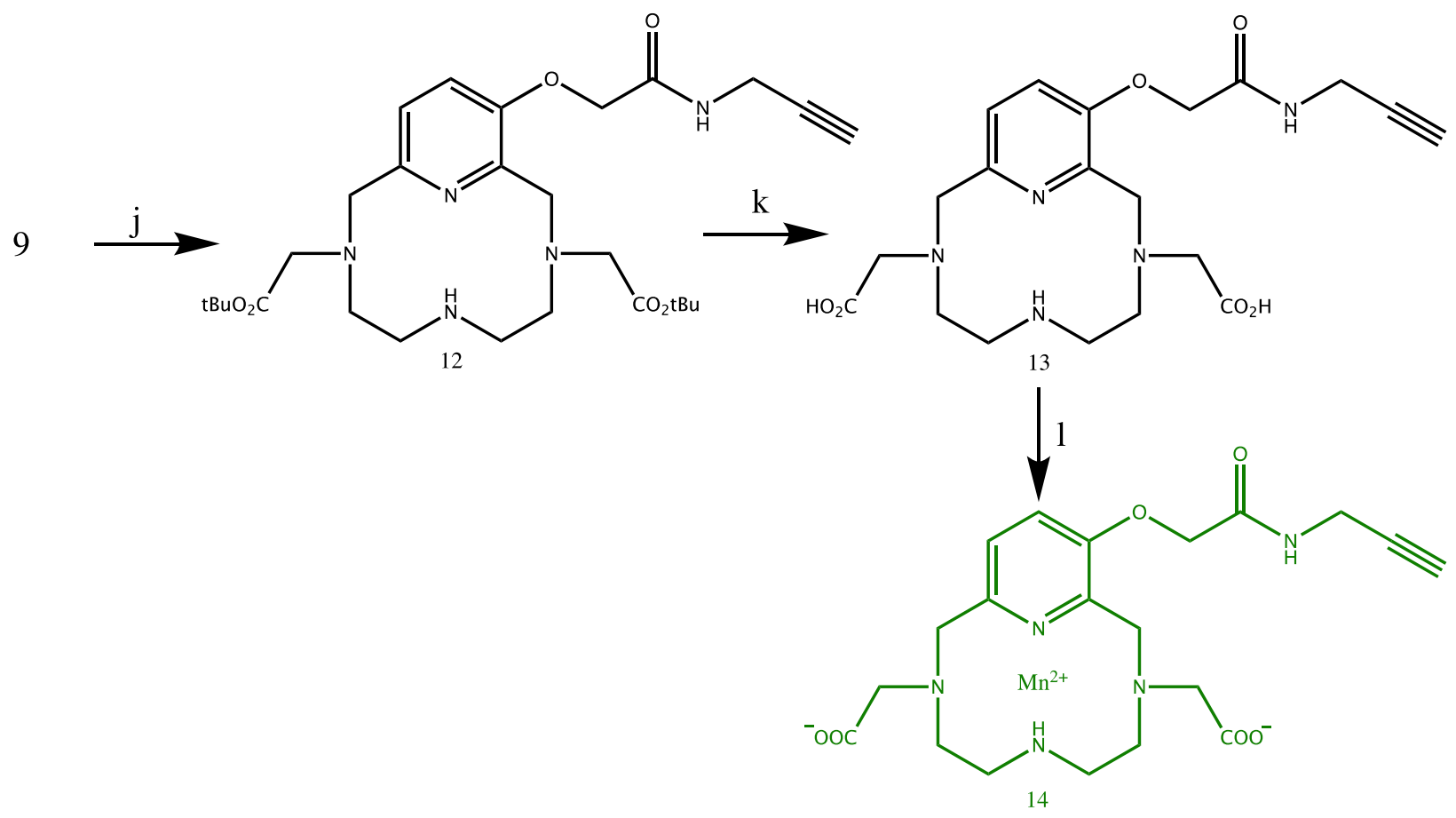

Scheme 4. Synthesis of (j) $\mathrm{HBTU}, \mathrm{NH}_{2} \mathrm{CH}_{2} \mathrm{CCH}$, DIPEA, $\mathrm{CH}_{2} \mathrm{Cl}_{2}$, r.t. 4 h30 (k) TFA, $\mathrm{CH}_{2} \mathrm{Cl}_{2}$, r.t. 1 day (1) $\mathrm{MnCl}_{2} \cdot 4 \mathrm{H}_{2} \mathrm{O}, \mathrm{H}_{2} \mathrm{O}, \mathrm{pH}=5-6,40^{\circ} \mathrm{C}$ overnight. The final product is compound $\left(\mathrm{MnL}_{3} \mathrm{CH}\right)$.

On the other hand, the ethyl ester derivative $\mathbf{7 b}$ was submitted to aminolysis in ethylenediamine at room temperature for 1 hour and led to the expected amido derivative $\mathbf{1 5}$ in $58 \%$ yield. Compound 15 was then submitted to acidolyses with hydrogen bromide in warmed acetic acid to cleave both the tert-butyl ester and the carbamate functions and led to the expected ligand 16a in $72 \%$ yield. It is noteworthy that upon treatment with hydrogen chloride in diethyl ether solution at room temperature, even repeatedly, only partial cleavage of the benzyloxycarbamate function was observed and gave a mixture of the desired compound 16a and of the intermediate $\mathbf{1 6 b}$ (as hydrochloride forms). Complexation with $\mathrm{Mn}^{2+}$ finally proceeded very easily, in few minutes at room temperature (Scheme 5). 


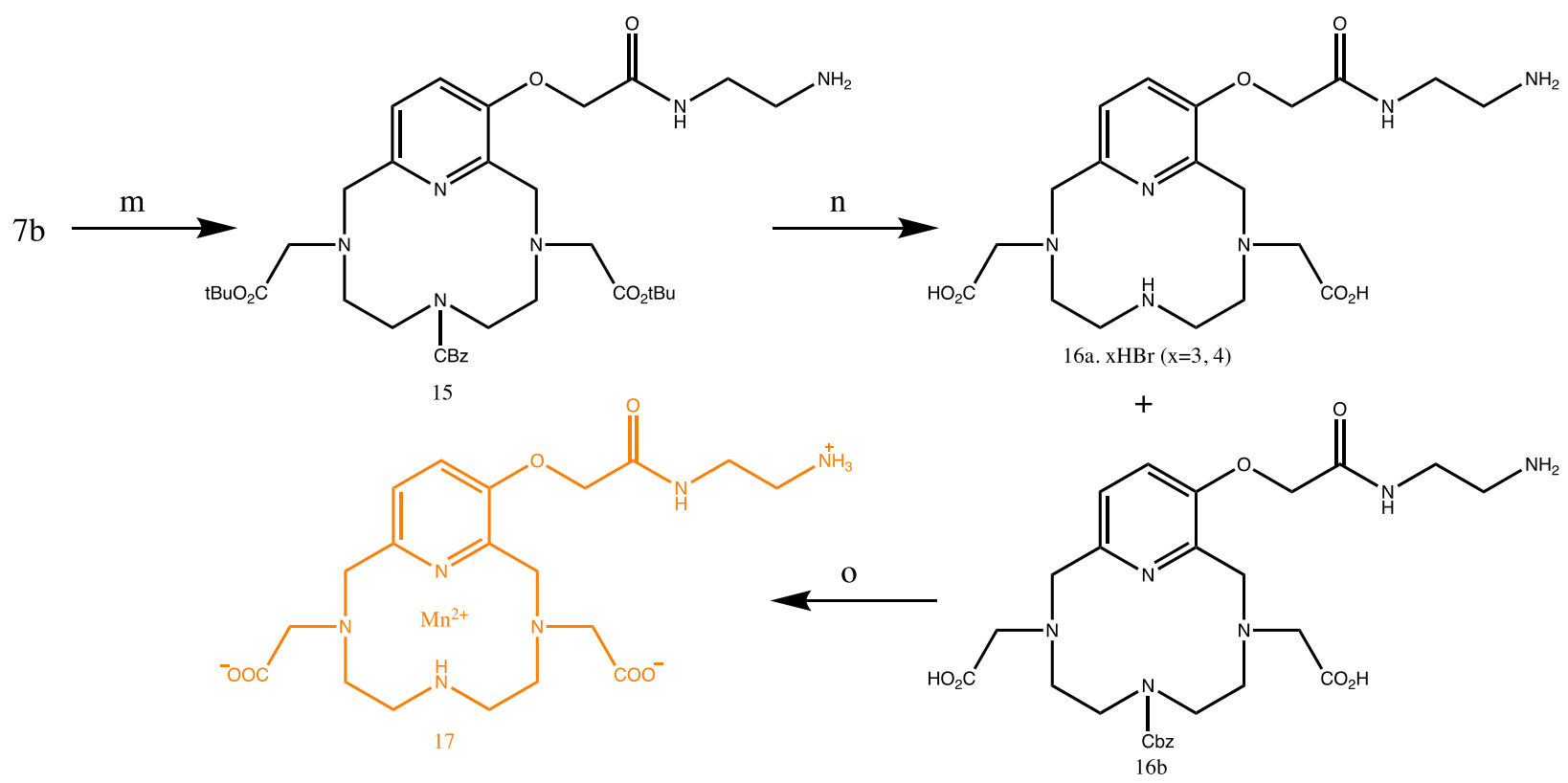

Scheme 5. Synthesis of (m) $\mathrm{NH}_{2} \mathrm{CH}_{2} \mathrm{CH}_{2} \mathrm{NH}_{2}$, r.t. (n) $\mathrm{HCl}_{\mathrm{anh}}, \mathrm{Et}_{2} \mathrm{O}$ or $\mathrm{HBr}_{\mathrm{anh}}, \mathrm{AcOH}, 70^{\circ} \mathrm{C}$ then r.t. (o) $\mathrm{MnCl}_{2} .4 \mathrm{H}_{2} \mathrm{O}, \mathrm{H}_{2} \mathrm{O}$, $\mathrm{pH}$ 5-6, r.t.. The final product is compound $\left(\mathrm{MnL}_{4} \mathrm{NH}_{3}{ }^{+}\right.$).

In order to ensure that manganese is in the oxidation state +2 , the complexations were performed under argon atmosphere and a reducing agent, sodium dithionite (approximately 1.3 eq $\mathrm{Na}_{2} \mathrm{~S}_{2} \mathrm{O}_{4}$ ), was added to the solutions with the $\mathrm{pH}$ maintained between 7 and $8 .{ }^{22}$

\section{Relaxometric characterization}

\section{Determination of the number of coordinated water molecules}

The determination of the number of water molecules in the inner coordination sphere $(q)$ is very important to estimate the efficacy of the complexes as MRI contrast agents, as the longitudinal proton relaxivity $r_{1}$ is directly related to the number of coordinated water molecules, in permanent exchange with those of the solvent. Two different techniques were used to determine this $q$ parameter for the $\mathrm{Mn}(\mathrm{II})$ complexes, developed respectively by $\mathrm{E}$. Gale et al. 
and J. Peters and C. Geraldes. The first technique is based on ${ }^{17} \mathrm{O}$ NMR spectroscopy where the water transverse relaxivity $r_{2}$ is measured as a function of temperature. ${ }^{34}$ (Figure 3) The method is then based on the maximum ${ }^{17} \mathrm{O}$ transverse relaxivity, $r^{0}{ }_{2 \max }$, measured in this case at low temperature (equation 1). This equation is obtained by different approximations, as explained by E. Gale et al., and the $r^{0}{ }_{2 \max }$ measured at $11.75 \mathrm{~T}$ lead to the results shown in Table 1 . The number $q$ is approximately the same for all complexes and close to one. ${ }^{34}$ To confirm these results, a second technique was used, based on the measurement of NMRD profiles (i.e. the water proton longitudinal relaxivity $r_{1}$ as a function of magnetic field or proton resonance frequency) at $25^{\circ} \mathrm{C}$, developed by J. Peters and C. Geraldes. ${ }^{35}$ (Figure 4) This is based on another equation related to the proton longitudinal relaxivity at low field (on the plateau of the NMRD profile) and the formula weight (FW) of the complex (equation 2). The results (Table 1) confirm the presence of one coordinated water molecule in the inner sphere for the four synthesized complexes. The slight difference between the results coming from the two techniques can be explained by the fact that both methods rely on different approximations. The presence of one coordinated water molecules is an interesting result since it shows that the presence of the arm on the pyridine moiety, with or without amide bond, does not change the number of coordinated water molecules, meaning that this appended functionality does not participate to the coordination bounds with the manganese ion. It will thus allow further grafting of molecules of interest in a forthcoming study. 


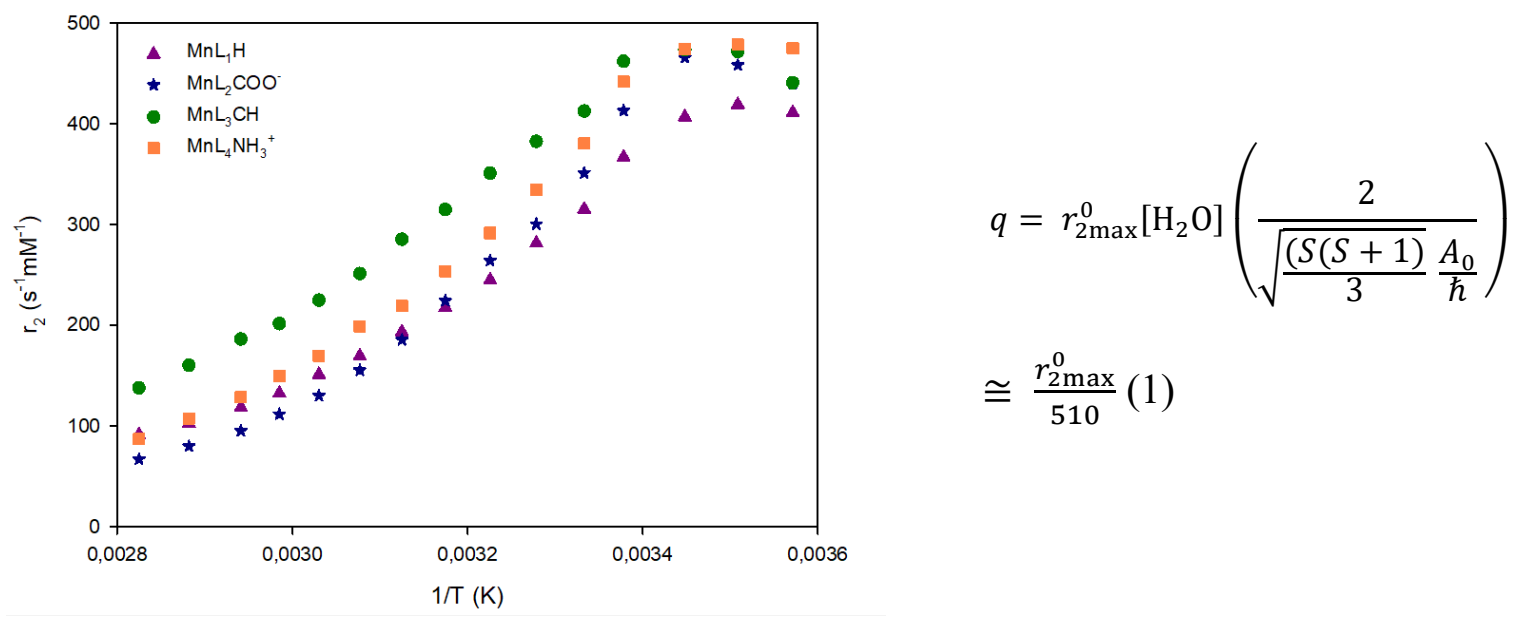

Figure 3. Measurements of the ${ }^{17} \mathrm{O}$ water transverse relaxivity versus inverse of temperature, at $11.75 \mathrm{~T}$, in the presence of the different $\mathrm{Mn}$-complexes at $2.06 \mathrm{mM}\left(\mathrm{MnL}_{1} \mathrm{H}\right.$, triangles),

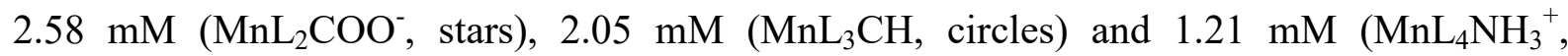
squares) concentration in order to determine the number of inner sphere water molecule $(q)$ from Formula (1) derived in reference 34 as a function of the maximum value $r_{2 \max }^{0}$.

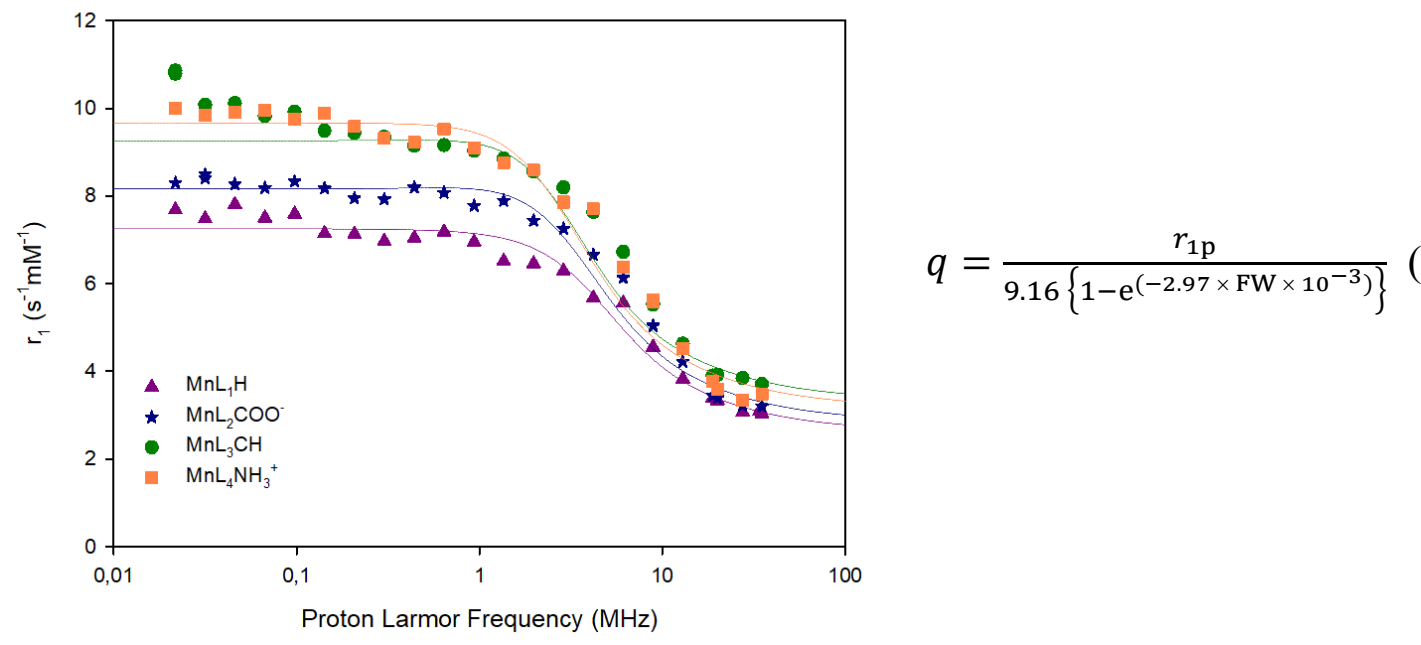

Figure 4. NMRD profiles at $25^{\circ} \mathrm{C}$ in order to determine the number of inner sphere water 
molecule $(q)$ from Formula (2) derived in reference 35 as a function of the plateau value $\left(r_{1 \mathrm{p}}\right)$ at low frequency and the formula weight $(\mathrm{FW})$ for the four complexes: $\mathrm{MnL}_{1} \mathrm{H}$ (triangles), $\mathrm{MnL}_{2} \mathrm{COO}^{-}$(stars), $\mathrm{MnL}_{3} \mathrm{CH}$ (circles) and $\mathrm{MnL}_{4} \mathrm{NH}_{3}{ }^{+}$(squares).

Table 1. Evaluation of the number of coordinated water molecules in the inner sphere for all complexes by two different techniques

\begin{tabular}{lcccc}
\hline & $r^{0}{ }_{2 \max }\left(\mathrm{s}^{-1} \cdot \mathrm{mM}^{-1}\right)$ & $q$ (Eq. 1) & $\begin{array}{c}r_{1 \mathrm{p}}\left(\mathrm{s}^{-1} \cdot \mathrm{mM}^{-1}\right) \\
\left(25^{\circ} \mathrm{C} \text { and }\right. \\
0.02 \mathrm{MHz})\end{array}$ & $q$ (Eq. 2) \\
\hline $\mathrm{MnL}_{1} \mathrm{H}$ & $41.8 \mathrm{MHz})$ & & 7.7 & $1.25 \pm 0.4$ \\
$\mathrm{MnL}_{2} \mathrm{COO}^{-}$ & 458.4 & $0.90 \pm 0.2$ & 8.3 & $1.30 \pm 0.4$ \\
$\mathrm{MnL}_{3} \mathrm{CH}$ & 473.4 & $0.93 \pm 0.2$ & 9.4 & $1.35 \pm 0.4$ \\
$\mathrm{MnL}_{4} \mathrm{NH}_{3}^{+}$ & 478.6 & $0.94 \pm 0.2$ & 10.0 & $1.42 \pm 0.4$ \\
\hline
\end{tabular}

\section{Determination of the exchange rate of the coordinated water molecule}

The technique which allows to determine the lifetime of the coordinated water molecule was developed by T. Swift and R. Connick. ${ }^{36}$ It is based on the measurement of the ${ }^{17} \mathrm{O}$ transverse relaxation rate as a function of temperature, as for the determination of $q$ for the $\mathrm{Mn}$ (II) complexes. (Figure 5). The results (Table 2) show that the coordinated water molecule is in a fast exchange regime for the four complexes studied since residence times $\tau_{\mathrm{M}}$ of the order of $6 \mathrm{~ns}$ are obtained. 


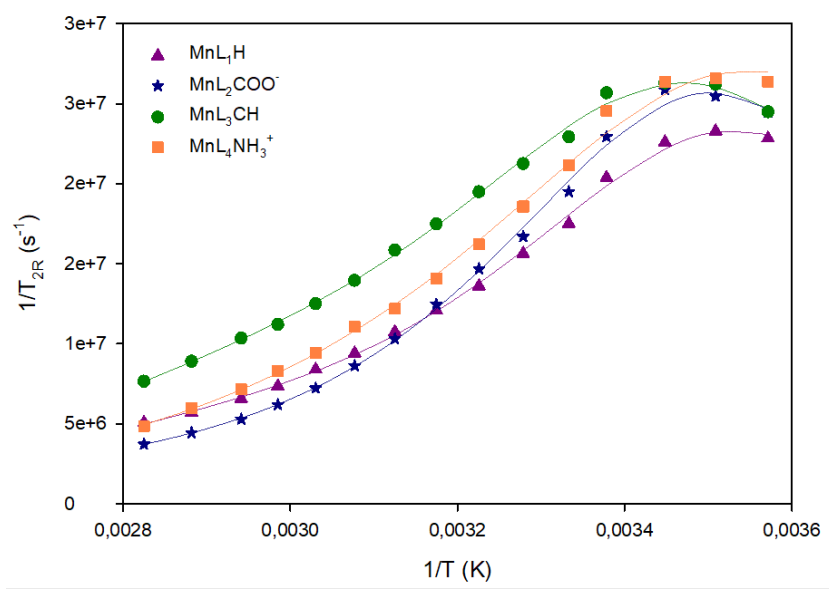

Figure 5. Measurement of the ${ }^{17} \mathrm{O}$ water transverse relaxation rate as a function of the inverse of temperature, at $11.75 \mathrm{~T}$, on solutions of each complex at $2.06 \mathrm{mM}\left(\mathrm{MnL}_{1} \mathrm{H}\right.$, triangles $), 2.58 \mathrm{mM}$ $\left(\mathrm{MnL}_{2} \mathrm{COO}^{-}\right.$, stars), $2.05 \mathrm{mM}\left(\mathrm{MnL}_{3} \mathrm{CH}\right.$, circles) and $1.21 \mathrm{mM}\left(\mathrm{MnL}_{4} \mathrm{NH}_{3}{ }^{+}\right.$, squares $)$. The continuous lines represent fits by the theoretical model developed in reference 36, with the parameters displayed in Table 2 .

Table 2. Determination of the residence time at $37^{\circ} \mathrm{C}$ and $11.75 \mathrm{~T}$ of the coordinated water molecule $\left(\tau_{\mathrm{M}}\right)$, as well as the other parameters characterizing this exchange $: A / \hbar$, the hyperfine coupling constant between the oxygen nucleus of the bound water molecule and the $\mathrm{Mn}^{2+}$ ion; $\tau_{\mathrm{v}}$, the correlation time modulating the electronic relaxation of $\mathrm{Mn}^{2+} ; E_{\mathrm{v}}$, the activation energy related to $\tau_{\mathrm{v}} ; B$, related to the mean-square value of the zero-field splitting energy $\Delta\left(B=2.4 \Delta^{2}\right)$; and $\Delta H^{\ddagger}$ and $\Delta S^{\ddagger}$ the enthalpy and entropy of activation, respectively, of the water exchange process. The number of coordinated water molecules was set to $q=1$. 


\begin{tabular}{lccccccc}
\hline & $\begin{array}{c}\tau_{M} \\
(\mathrm{~ns})\end{array}$ & $\begin{array}{c}\Delta H^{\neq} \\
\left(\mathrm{kJmol}^{-1}\right)\end{array}$ & $\begin{array}{c}\Delta S^{\neq} \\
\left(\mathrm{Jmol}^{-1} \mathrm{~K}^{-1}\right)\end{array}$ & $\begin{array}{c}\mathrm{A} / \hbar \\
\left(10^{6} \mathrm{rads}^{-1}\right)\end{array}$ & $\begin{array}{c}\mathrm{B} \\
\left(10^{20} \mathrm{~s}^{-2}\right)\end{array}$ & $\begin{array}{c}\tau_{\mathrm{V}}^{298} \\
(\mathrm{ps})\end{array}$ & $\begin{array}{c}E_{v} \\
\left(\mathrm{kJmol}^{-1}\right)\end{array}$ \\
\hline $\mathrm{MnL}_{1} \mathrm{H}$ & $6.5 \pm 0.4$ & $29.7 \pm 0.1$ & $7.4 \pm 0.2$ & $-39.9 \pm 2.5$ & $3.3 \pm 0.1$ & $1.4 \pm 0.1$ & $33.2 \pm 3.1$ \\
$\mathrm{MnL}_{2} \mathrm{COO}^{-}$ & $6.1 \pm 0.7$ & $32.4 \pm 0.2$ & $16.7 \pm 0.3$ & $-39.9 \pm 0.8$ & $5.2 \pm 0.6$ & $3.2 \pm 0.5$ & $36.3 \pm 4.6$ \\
$\mathrm{MnL}_{3} \mathrm{CH}$ & $8.4 \pm 0.9$ & $26.3 \pm 0.2$ & $-5.7 \pm 0.3$ & $-37.8 \pm 1.15$ & $1.2 \pm 0.1$ & $1.2 \pm 0.4$ & $36.9 \pm 7.5$ \\
$\mathrm{MnL}_{4} \mathrm{NH}_{3}{ }^{+}$ & $6.35 \pm 0.7$ & $25.1 \pm 0.1$ & $-7.4 \pm 0.8$ & $-32.2 \pm 0.7$ & $0.2 \pm 0.3$ & $1.6 \pm 2.0$ & $39.9 \pm 38.1$ \\
\hline
\end{tabular}

\section{Relaxometric measurements and NMRD profiles to assess the efficiency as MRI CA}

As a reminder, the relaxivity is defined as the increase of the water proton relaxation rate induced by one mmol per liter of paramagnetic complexes. Longitudinal $\left(r_{1}\right)$ relaxivities were measured at $37^{\circ} \mathrm{C}$ and respectively $0.47 \mathrm{~T}(20 \mathrm{MHz})$ and $1.41 \mathrm{~T}(60 \mathrm{MHz})$ (Table 3). They are lower than that of the commercially available gadolinium complexes (the data for Gd-DOTA are, for comparison, $3.5 \mathrm{~s}^{-1} \cdot \mathrm{mM}^{-1}$ at $20 \mathrm{MHz}$ and $3.1 \mathrm{~s}^{-1} \cdot \mathrm{mM}^{-1}$ at $60 \mathrm{MHz}$ and $37^{\circ} \mathrm{C}$ ), as expected part due to the intrinsic lower number of unpaired electrons for manganese (5) compared to that for gadolinium (7). The relaxivities could however be increased by grafting of the complexes on macromolecular entities that would reduce the tumbling rate of the complex, which enhances the interaction time between the nuclear magnetic moments of the water protons and the orbital one of the paramagnetic complex during an echo time of the NMR radiofrequency field pulse sequence, and therefore the spin relaxation mechanism. ${ }^{19}$ This is envisaged as outlook of this work in a near future.

NMRD profiles were performed for the four pyclen-based manganese complexes in order to evaluate the efficacy of each complex according to the magnetic field or frequency used. The fitting of these profiles according to the theory of Solomon and Bloembergen allows extracting important parameters to understand this efficacy such as the rotational correlation time $\left(\tau_{\mathrm{R}}\right)$ or 
"tumbling time", the electronic relaxation time at zero field $\left(\tau_{\mathrm{SO}}\right)$ and the correlation time that modulates electronic relaxation $\left(\tau_{\mathrm{V}}\right){ }^{37-39}$ Among the four complexes studied, $\mathrm{MnL}_{1} \mathrm{H}$, has a $r_{1}$ NMR dispersion profile below the other curves, especially at low field. This difference can be ascribed to the electronic properties of the complex which are slightly less favorable than for the other ones: $\tau_{\text {SO }}$ is indeed lower compared to the values of the three other complexes. This is again encouraging for the future studies where we plan to graft other molecules thanks to the arm present on the pyridine moiety. (Figure 6)

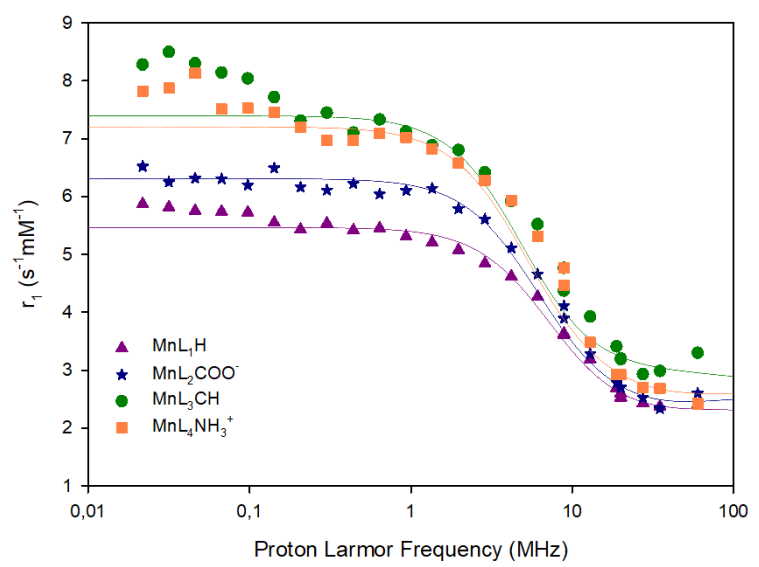

Figure 6. ${ }^{1} \mathrm{H}$ NMRD profiles at $37^{\circ} \mathrm{C}$ for $\mathrm{Mn}^{2+}$-complexes, showing the longitudinal relaxivity at varying proton Larmor frequency (aka varying magnetic field). The straight lines show the theoretical fitting based on the theory of Bloembergen and Solomon. ${ }^{37-39}$

Table 3. Results of the theoretical fitting of ${ }^{1} \mathrm{H}$ NMRD profiles at $37^{\circ} \mathrm{C}$ with Bloembergen and Solomon's theory using the MINUIT minimization software. Parameters, such as the distance of closest approach $\left(d_{\mathrm{NMR}}\right)$ and the water diffusion coefficient $(D)$ governing the outer sphere mechanism, or the distance between the coordinated proton of the water molecule and the manganese ion $(r)$ related to the inner sphere mechanism, can be set constant during the fitting 
procedure thank to their prior determinations along the study of the manganese complex properties. $^{37-39}$ The values of $q$ and $\tau_{\mathrm{M}}$ used were also predetermined thanks to their separate evaluation described above, thereby allowing to evaluate the rotational correlation time $\left(\tau_{\mathrm{R}}\right)$, the electronic relaxation time to ground level at zero magnetic field $\left(\tau_{\mathrm{SO}}\right)$ and the correlation time that modulates electronic orbital relaxation $\left(\tau_{\mathrm{V}}\right)$ at $37^{\circ} \mathrm{C}$.

\begin{tabular}{ccccc} 
& $\mathrm{MnL}_{1} \mathrm{H}$ & $\mathrm{MnL}_{2} \mathrm{COO}^{-}$ & $\mathrm{MnL}_{3} \mathrm{CH}$ & $\mathrm{MnL}_{4} \mathrm{NH}_{3}{ }^{+}$ \\
\hline$d_{\mathrm{NMR}}(\mathrm{nm})[\mathrm{a}]$ & 0.36 & 0.36 & 0.36 & 0.36 \\
$D\left(\mathrm{~m}^{2} \cdot \mathrm{s}^{-1}\right)[\mathrm{a}]$ & $3.3 \times 10^{-9}$ & $3.3 \times 10^{-9}$ & $3.3 \times 10^{-9}$ & $3.3 \times 10^{-9}$ \\
$r(\mathrm{~nm})[\mathrm{a}]$ & 0.28 & 0.28 & 0.28 & 0.28 \\
$\tau_{\mathrm{R}}(\mathrm{ps})[\mathrm{b}]$ & $48.7 \pm 3.8$ & $57 \pm 5.2$ & $65.6 \pm 0.85$ & $59 \pm 0.6$ \\
$\tau_{\mathrm{M}}(\mathrm{ns})[\mathrm{a}]$ & 6.5 & 6.1 & 8.4 & 6.35 \\
$\tau_{\mathrm{SO}}(\mathrm{ps})[\mathrm{b}]$ & $119 \pm 19.2$ & $155 \pm 29.5$ & $224 \pm 31.6$ & $3.1 \pm 61.6$ \\
$\tau_{\mathrm{v}}(\mathrm{ps})[\mathrm{b}]$ & $5.7 \pm 1.2$ & $3.4 \pm 0.7$ & $8.7 \pm 8.0$ & 1 \\
$q[\mathrm{a}]$ & 1 & 1 & 1 & 2.9 \\
$r_{1}$ at $20 \mathrm{MHz}$ & 2.6 & 2.7 & 3.2 & 2.4 \\
$\left(\mathrm{~s}^{-1} \cdot \mathrm{mmol}{ }^{-1} \cdot \mathrm{L}\right)$ & & 2.6 & 3.3 &
\end{tabular}

[a] Parameters pre-set at constant values during the fitting procedure [b] Parameters obtained by the fitting of NMRD profiles with Bloembergen and Solomon's model.

\section{Transmetalation evaluation}

It is now well-established that the kinetic inertness of a complex is a more important parameter than its intrinsic thermodynamic stability for in vivo applications. In order to define the stability of the manganese complexes against the most important endogenous divalent metal cations present in body fluids $\left(\mathrm{Zn}^{2+}, \mathrm{Cu}^{2+}, \mathrm{Ca}^{2+}, \mathrm{Mg}^{2+}\right)$, a transmetalation study was performed in the presence of $\mathrm{Zn}(\mathrm{II})$ as exchanging metal cation. The choice of $\mathrm{Zn}^{2+}$ as challenger to assess the in 
vivo transmetalation behavior of the $\mathrm{Mn}$ (II) complexes was governed by the following considerations: $:^{40,41}$ i) none of the four competitive endogenous cations is paramagnetic and therefore does respond to NMR; ii) $\mathrm{Zn}^{2+}$ is the second most abundant transition metal in the human body (33 ppm) after $\mathrm{Fe}^{3+}(60 \mathrm{ppm})$; iii) for a given exogenous ligand, complexes of $\mathrm{Zn}^{2+}$ as well as $\mathrm{Cu}^{2+}$ have generally higher stability than the corresponding $\mathrm{Mn}^{2+}$ complex as ascribed to LFSE effect (ligand field stabilization energy), whereas alkaline earth ions $\mathrm{Ca}^{2+}$ and $\mathrm{Mg}^{2+}$, although present at higher concentrations in blood plasma than $\mathrm{Zn}^{2+}$, form generally less stable complexes with the exogenous ligands generally studied for $\mathrm{Mn}^{2+}$ due to their absence of $\mathrm{d}$ electronic orbitals; iv) the concentration of $\mathrm{Zn}^{2+}$ in blood is higher compared to that of $\mathrm{Cu}^{2+}$ ( 5 to 100 times higher). ${ }^{42}$ As previously described by us, ${ }^{41,43}$ the transmetalation rate was assessed by measuring the progress of the proton relaxivity at $37^{\circ} \mathrm{C}$ and $20 \mathrm{MHz}$. The method consists in using a solution of the Mn-complexes at concentration $2.5 \mathrm{mM}$ in phosphate buffer in the presence of an equimolar amount of zinc chloride. The proton longitudinal relaxation time $\left(T_{1}\right)$ is then measured in order to determine paramagnetic relaxation rate $R_{1}{ }^{\mathrm{p}}$ as a function of time. Indeed, when the exchange between $\mathrm{Mn}^{2}$ and $\mathrm{Zn}^{2+}$ takes place, a precipitate of manganese phosphate $\left(\mathrm{Mn}_{3}\left(\mathrm{PO}_{4}\right)_{2}\right)$ is formed. This process leads to increase of $T_{1}$ and thus decrease of $R_{1}{ }^{\mathrm{p}}$ compared to its initial value $R_{1}^{\mathrm{p}}(t=0)$, as ascribed to decrease of paramagnetic ion concentration in solution.

The results (Figure 7) are similar for all the Mn complexes studied and show, during the first day, a small fast yet transient increase of the ratio $R_{1}{ }^{\mathrm{p}} / R_{1}^{\mathrm{p}}(t=0)$, which could be due to the presence of transient polynuclear species coordinated to both $\mathrm{Mn}^{2+}$ and $\mathrm{Zn}^{2+}$. This step is followed by a decrease of about $50 \%$ of the relaxation rate due to the formation of the insoluble solid as explained previously. This decrease is however quite slow ( $t_{1 / 2}$ half-life of approximately 
$1350 \mathrm{~min}$ ) and we can notice that at the first measurement of the second day, the relaxation rate reached $80 \%$ of the initial value of relaxation rate. As a conclusion, even though this study highlights a lack of kinetic stability towards the transmetalation with zinc ions after a long time, we can be confident for the use of those complexes in vivo given their expected fast clearance from the organism. Further in vitro toxicity and in vivo pharmacokinetic studies will however be necessary in the future to definitively demonstrate the biosafety of these paramagnetic MRI CAs.

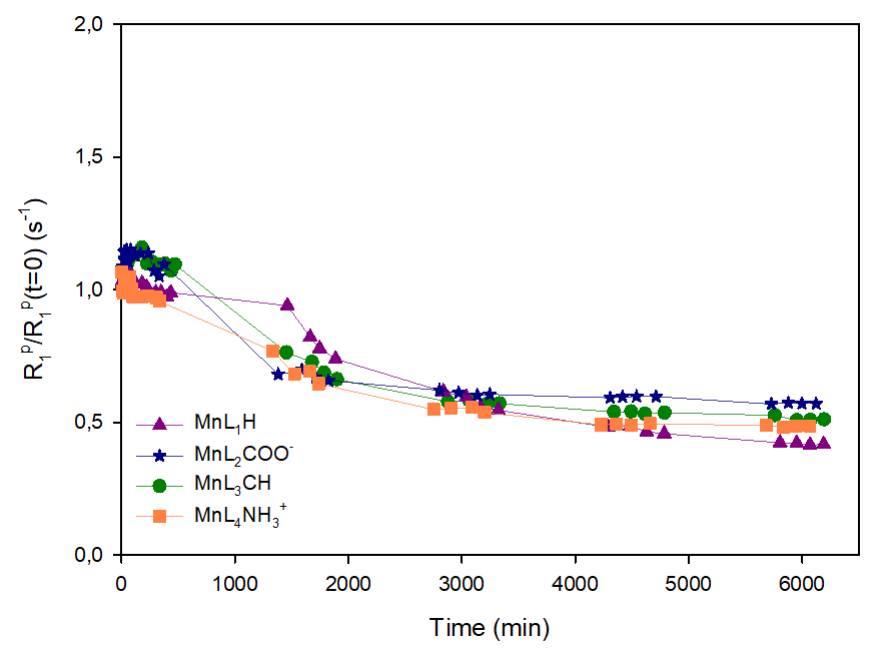

Figure 7. Evolution of the normalized paramagnetic longitudinal relaxation rate in order to evaluate the transmetalation kinetics between manganese and zinc ions for the four $\mathrm{Mn}^{2+}$ complexes: $\mathrm{MnL}_{1} \mathrm{H}$ (triangles), $\mathrm{MnL}_{2} \mathrm{COO}^{-}$(stars), $\mathrm{MnL}_{3} \mathrm{CH}$ (circles) and $\mathrm{MnL}_{4} \mathrm{NH}_{3}{ }^{+}$(squares). Experiment was performed during 5 days in phosphate buffer at $20 \mathrm{MHz}$ and $37^{\circ} \mathrm{C}$. The concentration of Mn-complexes and of competing $\mathrm{Zn}(\mathrm{II})$ salt used is $2.5 \mathrm{mM}$, which is much higher than its normal physiological level $(\sim 10 \mu \mathrm{M}) .^{44}$

\section{Phantom images}


As a proof of concept of the use of these manganese-complexes as MRI CAs, phantom MRI images were recorded both at preclinical (9.4 T) and clinical magnetic field (1 T), for each manganese complex at a concentration of $0.5 \mathrm{mM}$ and compared with Gd-DOTA at the same concentration and with water (Figure 8). As expected, the images are highlighted for the four Mn-complexes compared to water but their contrast is less enhanced than with Gd-DOTA. Among the Mn-complexes, we can also notice a smaller highlighting effect for $\mathrm{MnL}_{1} \mathrm{H}$, which can be related to its smaller relaxivity because of the absence of the arm on the pyridine structure (Table 3).

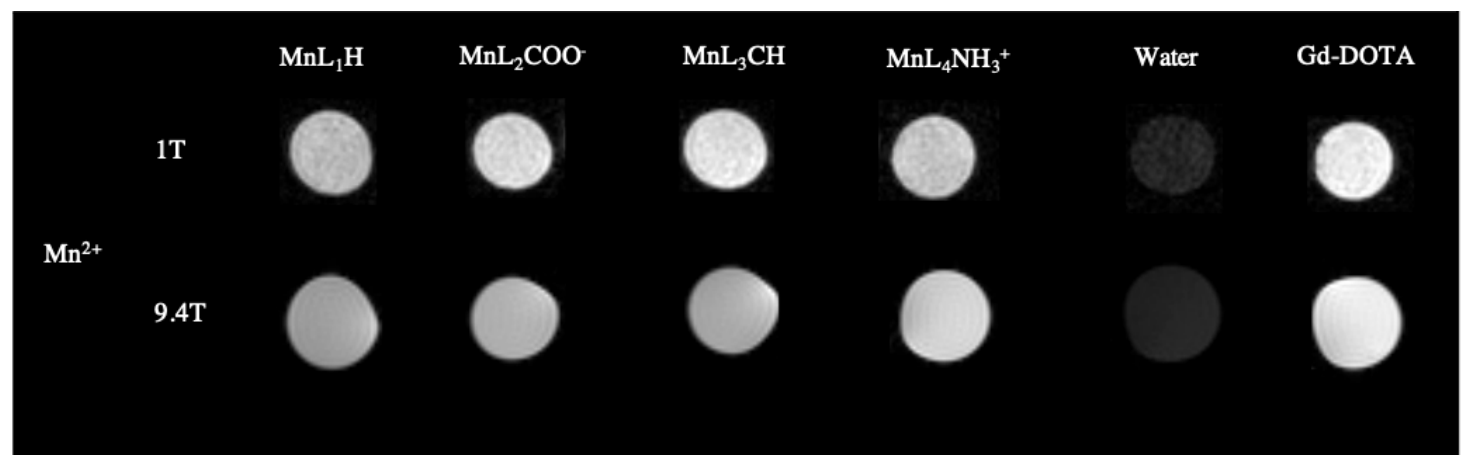

Figure 8. Phantom images recorded at approximately $37^{\circ} \mathrm{C}$ under two different magnetic fields (1 $\mathrm{T}$ and $9.4 \mathrm{~T}$ ) of each $\mathrm{Mn}^{2+}$-complex at a concentration of $0.5 \mathrm{mM}$ compared with a commercial Gd-complex, Gd-DOTA, at the same concentration, and with pure water.

Table 3. Values of longitudinal relaxivity calculated from the water proton relaxation time $T_{1}$ measured at approximately $37^{\circ} \mathrm{C}$ under a field of 9.4T $(400 \mathrm{MHz})$.

\begin{tabular}{llllll} 
& $\mathrm{MnL}_{1} \mathrm{H}$ & $\mathrm{MnL}_{2} \mathrm{COO}^{-}$ & $\mathrm{MnL}_{3} \mathrm{CH}$ & $\mathrm{MnL}_{4} \mathrm{NH}_{3}{ }^{+}$ & Gd-DOTA \\
\hline & & & & & \\
$r_{1}\left(\mathrm{~s}^{-1} \cdot \mathrm{mM}^{-1}\right)$ & $2.8 \pm 0.1$ & $2.7 \pm 0.1$ & $3.1 \pm 0.1$ & $2.95 \pm 0.1$ & $3.2 \pm 0.1$ \\
$9.4 \mathrm{~T}, 37^{\circ} \mathrm{C}$ & & & & & \\
\hline
\end{tabular}




\section{Conclusions and perspectives}

Four novel pyclen-based complexing agents were synthesized and the molecular structure of intermediated compounds after each step of the synthesis was characterized. The corresponding manganese complexes were prepared and fully characterized by NMR relaxometry methods to evaluate the parameters governing their properties and efficacy as paramagnetic MRI contrast agents. This characterization is important in order to evaluate if the complexes have an efficacy close to the commercial gadolinium complexes, and could potentially replace them on market, if they pass further evaluation of their bio-safety.

Although these Mn-based compounds have been shown to be slightly less effective than the marketed Gd-based compounds as ascribed to lower magnetic moment of the metal, the potential of these pyclen-based chelating compounds remains high. Their relaxivity could indeed be improved by different ways. Firstly, it will be possible to play on the rotational correlation time of the complex by blocking them in a nanostructure either organic (e.g. micelle or vesicle) or inorganic (e.g. silica nanoparticle), while keeping sufficiently small hydrodynamic size and stealthness to allow rapid clearance when injected in systemic circulation (which is a prerequisite for CAs used in clinics). Moreover, the additional chemical functions on the pyridine moiety will allow conjugation to biologically relevant vectors such as peptides or antibodies in order to target specific pathologies. Finally, on the basis of reported results, further improved kinetic inertness of the $\mathrm{Mn}^{2}$-complexes might be obtained in future by replacing the two acetate complexing groups by non-ionizable groups such as amides; in this case, the positive charge on the resulting cationic $\mathrm{Mn}^{2}$ complexes could be protective against acid-assisted dissociation, although grafting of neutral macromolecules might be necessary in that case to insure stealthness against 
adsorption of blood plasma proteins. It will nevertheless be important to verify that the presence of those amide functions does not increase too much the residence time in the inner sphere of the coordinated water molecule. As a conclusion, these preliminary results show very encouraging properties of pyclen derivatives for MRI contrast properties, although further study is necessary to demonstrate that they can replace gadolinium complexes in clinical diagnosis of diseases (cancers, strokes...) by MRI.

Experimental section

Materials

Chemical and physical measurements:

The NMR spectra $\left({ }^{1} \mathrm{H},{ }^{13} \mathrm{C}, \mathrm{COSY}, \mathrm{DEPT}\right)$ were recorded at $298 \mathrm{~K}$ and reported in ppm. (Bruker ${ }^{\circledR}$ AVANCEII-500 at $500 \mathrm{MHz}$, Bruker ${ }^{\circledR}$ AVANCE NEO at $400 \mathrm{MHz}$ or Bruker ${ }^{\circledR}$ AVANCE NEO at $600 \mathrm{MHz}$ ). The multiplicity of the peaks is defined as s (singlet), d (doublet), $\mathrm{t}$ (triplet) and $\mathrm{m}$ (multiplet). The reactions were monitored by mass spectrometry (Waters ${ }^{\circledR}, \mathrm{ZQ}-$ 2000) and all the compounds were characterized by mass spectrometry (Waters ${ }^{\circledR}$ ZQ-2000, Waters ${ }^{\circledR}$ QDa, Waters ${ }^{\circledR}$ Quattro Premier or Waters ${ }^{\circledR}$ QTofUs). The ESI-LRMS was performed on 3200 QTrap (AB Sciex). The $\mathrm{pH}$ was controlled by Mettler Toledo ${ }^{\circledR}$ fiveEasy $\mathrm{pH} / \mathrm{mV}$. The relaxometry and NMRD profiles measurements were performed on Bruker ${ }^{\circledR}$ MiniSpec at 20 and $60 \mathrm{MHz}$ at $37^{\circ} \mathrm{C}$ and on a fast field cycling (FFC) relaxometer between 0.02 and $40 \mathrm{MHz}$ (Spinmaster, Stelar ${ }^{\circledR}$, Italy). ${ }^{17} \mathrm{O}$ NMR measurements were performed on a Bruker ${ }^{\circledR}$ AVANCEII-500 at 67.8 MHz. The MRI measurements were performed on 1T (Bruker ${ }^{\circledR}$ ICON) and 9.4T (Bruker® Biospec) with a Rapid Acquisition with Relaxation Enhancement sequence 
$(\mathrm{RARE})(\mathrm{TE}=12 \mathrm{~ms}, \mathrm{TR}=350 \mathrm{~ms}$, resolution $=156 \times 146$ microns, $\mathrm{RARE}$ factor $=2,2$ or 4 averages, slice thickness $=1.25 \mathrm{~mm})$.

\section{Chemical material and methods:}

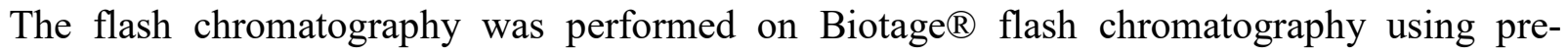
packed cartridges. The collection is based on absorption at 254 and $270 \mathrm{~nm}$ by UV detection.

Methods

\section{Synthesis of the lower part}

2-Nitro[N(2\{2[(2-nitrophenyl)sulfonylamino]ethylamino $\})$-ethyl]benzenesulfonamide compound 2: It is synthesized according to the protocol of Devreux et al. ${ }^{31}$

Benzyl N,N-bis(2-((2-nitrophenyl)sulfonylamino)ethyl)carbamate compound $\quad 3: \quad$ DIPEA (7.7 $\mathrm{mL}, 44.2 \mathrm{mmol}, 1.2 \mathrm{eq})$ is added to a solution of disulfonamido amine 2 (17.6 g, $37.1 \mathrm{mmol})$ in THF $(100 \mathrm{~mL})$, followed by benzyl chloroformate $(6.3 \mathrm{~mL}, 44.1 \mathrm{mmol}, 1.2 \mathrm{eq})$ in one portion. The reaction is stirred overnight during which insoluble matter appeared. The mixture is concentrated to dryness. The crude material is taken up in $\mathrm{CH}_{2} \mathrm{Cl}_{2}(100 \mathrm{~mL})$, and is washed with water $(4 \times 30 \mathrm{~mL})$. The organic layer is dried then concentrated to dryness to afford the desired 
compound 2 as a brown oil $(21.2 \mathrm{~g}, 34.8 \mathrm{mmol})$. Yield 94\%. ${ }^{1} \mathrm{H}$ NMR $\left(\mathrm{CDCl}_{3}, 400 \mathrm{MHz}\right) \delta$ (ppm): conformed to reported data of Kim et al. ${ }^{45}$

Di-tert-butyl 2,2'-(((((benzyloxy)carbonyl)azanediyl)bis(ethane-2,1-diyl))bis

(azanediyl))diacetate compound $\mathbf{5 b}$ : A suspension of the previously prepared compound 3 $(1.61 \mathrm{~g}, 2.65 \mathrm{mmol})$ with potassium carbonate $(810 \mathrm{mg}, 5.86 \mathrm{mmol}, 2.2 \mathrm{eq})$ in acetonitrile $(22 \mathrm{~mL})$ is refluxed for 15 minutes. tert-Butyl bromoacetate $(900 \mu \mathrm{L}, 6.09 \mathrm{mmol}, 2.3 \mathrm{eq})$ is added in one portion. The reaction is monitored by MS and/or TLC (Cyclohexane/AcOEt 1/1 v/v, UV detection). After $1.5 \mathrm{~h}$, total conversion of both the starting triamine $\mathbf{3}$, and of the mono- $N$ alkylated intermediate $\mathbf{4 a}$ is observed leading to the di- $N$-alkylated disulfonamide $\mathbf{4 b}$. The reaction mixture is cooled, and a second portion of potassium carbonate $(1.60 \mathrm{~g}, 11.92 \mathrm{mmol}$, $4.4 \mathrm{eq})$ is added, followed by thiophenol $(810 \mu \mathrm{L}, 7.94 \mathrm{mmol}, 3.0 \mathrm{eq})$ in one portion. The reaction is monitored by MS and/or TLC (Cyclohexane/AcOEt 1/1 v/v, UV detection: $\mathrm{CH}_{2} \mathrm{Cl}_{2} / \mathrm{MeOH} 97.5 / 2.5 \mathrm{v} / \mathrm{v}, \mathrm{UV}$ and ninhydrin stain detection). After 2.5h, total conversion of the intermediate compounds $\mathbf{4 b}$ and $\mathbf{5 a}$ is obtained. The reaction mixture is allowed to cool to room temperature. Insoluble matter is filtered off through Celite ${ }^{\circledR}$, and the organic filtrate is concentrated to dryness. The resulting canary yellow colored oil is purified by chromatography on silica gel $\left(\mathrm{CH}_{2} \mathrm{Cl}_{2} / \mathrm{MeOH} 10 / 0\right.$ to $\left.8 / 2 v / v\right)$ and led to the desired product $\mathbf{5 b}$ as an orange oil (1.051 g, $2.26 \mathrm{mmol})$. Yield 85\%. ${ }^{1} \mathrm{H}$ NMR $\left(\mathrm{CDCl}_{3}, 400 \mathrm{MHz}\right) \delta(\mathrm{ppm}): 1.44(\mathrm{~s}, 18 \mathrm{H},-\mathrm{tBu})$; 2.73-2.90 (m, 4H, -N-CH $\left.-\mathrm{CH}_{2}-\mathrm{N}-\right)$; 3.22-3.36 (m, 4H, -CH $\left.-\mathrm{CO} 2 \mathrm{tBu}\right) ; 3.44$ (broad s, 4H, -N$\left.\mathrm{CH}_{2}-\mathrm{CH}_{2}-\mathrm{N}\right) ; 5.12\left(\mathrm{~s}, 2 \mathrm{H},-\mathrm{CH}_{2}-\mathrm{Ph}\right) ; 7.26-7.38\left(\mathrm{~m}, 5 \mathrm{H}, \mathrm{CH}_{\mathrm{Ar}}\right) .{ }^{13} \mathrm{C} \mathrm{NMR}\left(\mathrm{CDCl}_{3}, 100 \mathrm{MHz}\right)$ $\delta(\mathrm{ppm}): 28.1(-\mathrm{tBu}) ; 47.7,48.0,48.2$, and $48.5\left(-\mathrm{N}-\mathrm{CH}_{2}-\mathrm{CH}_{2}-\mathrm{N}\right) ; 51.2\left(-\mathrm{CH}_{2}-\mathrm{CO}_{2} t \mathrm{Bu}\right) ; 67.3(-$ 
$\left.\mathrm{CH}_{2}-\mathrm{Ph}\right) ; 81.6\left(\mathrm{C}_{\text {quat }} \mathrm{tBu}\right) ; 127.9,128.0$, and $128.6\left(\mathrm{CH}_{\mathrm{Ar}}\right) ; 136.7\left(\mathrm{C}_{\text {quat }} \mathrm{Ph}\right) ; 156.4\left(-\mathrm{N}-\mathrm{CO}_{2} \mathrm{Ph}\right)$; $171.0\left(-\mathrm{CO}_{2} \mathrm{tBu}\right)$.

\section{Synthesis of the upper parts}

2,6-Bis(bromomethyl)pyridine compound 6a: It is synthesized according to the protocol of Dioury et $a .^{28}$

Ethyl ((2,6-bis(bromomethyl)pyridin-3-yl)oxy)acetate compound $\mathbf{6} \boldsymbol{b}$ : It is synthesized according to the protocol of Devreux et al. ${ }^{31}$

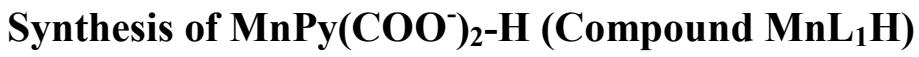

Benzyl 3,9-bis(2-tert-butoxy-2-oxo-ethyl)-3,6,9,15-tetrazabicyclo[9.3.1] pentadeca1(14),11(15),12-triene-6-carboxylate compound 7a: Solid $\mathrm{Na}_{2} \mathrm{CO}_{3}(480 \mathrm{mg}, 4.53 \mathrm{mmol}, 4 \mathrm{eq})$ is added to a solution of diamine lower part $\mathbf{5 b} \quad(530 \mathrm{mg}, 1.14 \mathrm{mmol})$ with 2,6-bis(bromomethyl)pyridine $\mathbf{6 a}(401 \mathrm{mg}, 1.52 \mathrm{mmol}, 1.3 \mathrm{eq})$ in acetonitrile $(115 \mathrm{~mL})$. The suspension is refluxed until completion of the reaction (MS and/or TLC monitoring; 1 hour). The insoluble matter is filtered off, and the filtrate is concentrated to dryness. The crude material obtained is purified by chromatography on silica gel $\left(\mathrm{CH}_{2} \mathrm{Cl}_{2} / \mathrm{MeOH}, 100 / 0\right.$ to $\left.98 / 2 v / v\right)$. to give the desired compound $7 \mathbf{a}$ as a thick oil $(253 \mathrm{mg}, 0.445 \mathrm{mmol})$. Yield $39 \% .{ }^{1} \mathrm{H} \mathrm{NMR}\left(\mathrm{CDCl}_{3}\right.$, $400 \mathrm{MHz}) \delta(\mathrm{ppm}): 1.43$, and $1.44\left(2 \mathrm{~s}^{\#}, 18 \mathrm{H},-\mathrm{tBu}\right) ; 2.68-2.90\left(\mathrm{~m}, 4 \mathrm{H},-\mathrm{N}-\mathrm{CH}_{2}-\mathrm{CH}_{2}-\mathrm{N}-\right)$; 3.163.27 (broad t, $J$ 7-7.80 Hz, 4H, -N-CH$-\mathrm{CH}_{2}-\mathrm{N}-$ ); 3.34, and 3.41 (2 broad s ${ }^{\#}, 4 \mathrm{H},-\mathrm{N}-\mathrm{CH}_{2}-$ ); $3.91-$ 
$4.06\left(\mathrm{~m}, 4 \mathrm{H},-\mathrm{N}-\mathrm{CH}_{2}-\right) ; 5.01\left(\mathrm{~s}, 2 \mathrm{H},-\mathrm{CH}_{2}-\mathrm{Ph}\right) ; 7.13-7.31\left(\mathrm{~m}, 7 \mathrm{H}, \mathrm{Ph}\right.$, and $\left.-\mathrm{CH}_{2}-\mathrm{C}(\mathrm{N})-\mathrm{CH}=\mathrm{CH}\right)$; $7.61\left(\mathrm{t}, J 7.6 \mathrm{~Hz}, 1 \mathrm{H},-\mathrm{CH}_{2}-\mathrm{C}(\mathrm{N})-\mathrm{CH}=\mathrm{CH}\right) .{ }^{\#}$ Double signal that may be due to rotamers (carbamate bond: free-rotation obstruction) ${ }^{13} \mathrm{C} \mathrm{NMR}\left(\mathrm{CDCl}_{3}, 100 \mathrm{MHz}\right) \delta(\mathrm{ppm}): 28.2(-\mathrm{tBu})$; 44.9, and $45.3^{\$}\left(-\mathrm{N}-\mathrm{CH}_{2}-\mathrm{CH}_{2}-\mathrm{N}-\right)$; 51.6, and $52.1^{\$}\left(-\mathrm{N}-\mathrm{CH}_{2}-\mathrm{CH}_{2}-\mathrm{N}-\right)$; 59.0 , and 59.2 $\left(-\mathrm{N}^{-} \mathrm{CH}_{2}-\right)$; 60.0, and 60.2 $\left(-\mathrm{N}-\mathrm{CH}_{2}-\right) ; 66.8\left(-\mathrm{CH}_{2}-\mathrm{Ph}\right) ; 81.2\left(\mathrm{C}_{\text {quat }} \mathrm{Bu}\right) ; 122.9\left(-\mathrm{CH}_{2}-\mathrm{C}(\mathrm{N})-\mathrm{CH}=\mathrm{CH}\right) ; 127.6$, $127.8,128.4\left(3 \mathrm{CH}_{\mathrm{Ar}} \mathrm{Ph}\right) ; 137.0\left(\mathrm{C}_{\text {quat }} \mathrm{Ph}\right) ; 137.5\left(-\mathrm{CH}_{2}-\mathrm{C}(\mathrm{N})-\mathrm{CH}=\mathrm{CH}\right) ; 156.1,157.3,157.7^{\&}$ $\left(\mathrm{NCO}_{2}\right.$, and $2 \mathrm{C}_{\text {quat }}$ Pyr $) ; 170.6\left(\mathrm{CO}_{2}\right) .{ }^{\$}$ Although the symmetrical structure, each ${ }^{13} \mathrm{C}$ appears to be diastereotopic; that may be due to rotamers from the carbamate bond (free-rotation obstruction). ${ }^{\circledR}$ Broad and small signal.

tert-Butyl 2-\{9-[2-(tert-butoxy)-2-oxoethyl]-3,6,9,15-tetraazabicyclo[9.3.1] pentadeca1(14),11(15),12-trien-3-yl\}acetate compound 8a: Compound 7a (240 $\mathrm{mg}, 0.42 \mathrm{mmol})$ is solubilized in EtOH following by the addition of $\mathrm{Pd} / \mathrm{C}(24 \mathrm{mg})$. The solution is stirred 10 days under under $\mathrm{H}_{2}$ at atmospheric pressure. Insoluble material is filtered through Celite ${ }^{\circledR}$ and the filtrate is concentrated at relatively high temperature to eliminate the toluene which is the byproduct to give the desired compound $\mathbf{8 a}$. The crude product is directly engaged in the next synthesis step. ${ }^{1} \mathrm{H}$ NMR $\left(\mathrm{CD}_{3} \mathrm{OD}, 500 \mathrm{MHz}\right) \delta(\mathrm{ppm}): 1.46$ (s, 18H, -tBu); 2.64-3.01 (broad s, $\left.4 \mathrm{H},-\mathrm{N}-\mathrm{CH}_{2}-\mathrm{CH}_{2}-\mathrm{N}-\right)$; 3.31 (broad t, $J 5.3 \mathrm{~Hz} 4 \mathrm{H},-\mathrm{N}-\mathrm{CH}_{2}-\mathrm{CH}_{2}-\mathrm{N}-$ ); 3.51 (s, 2H, N-CH $\mathrm{H}_{2}-\mathrm{N}-$ ); $3.99\left(\mathrm{~s}, 4 \mathrm{H},-\mathrm{CH}_{2}-\mathrm{CO}_{2} \mathrm{tBu}\right) ; 7.01(\mathrm{~d}, J 7.66 \mathrm{~Hz}, 1 \mathrm{H},-\mathrm{CH}=\mathrm{CH}-\mathrm{CH}=) ; 7.56(\mathrm{t}, J 7.65 \mathrm{~Hz}, 1 \mathrm{H},-$ $\mathrm{CH}=\mathrm{C} H-\mathrm{CH}=)$.

2-[9-(Carboxymethyl)-3,6,9,15-tetraazabicyclo[9.3.1]pentadeca-1(14),11(15),12-trien-3yl]acetic acid compound 10a: Compound 8a (10 mg; $0.023 \mathrm{mmol})$ is solubilized in 
dichloromethane $(1 \mathrm{~mL})$ and stirred following by the addition of trifluoroacetic acid $(1 \mathrm{~mL})$. Overnight, the solution is concentrated and washed two times with diethylether $(4 \mathrm{~mL})$ to give the desired compound 10a (12 mg, 0.018mmol). Yield $79.8 \%$ (determined by weighing). ${ }^{1} \mathrm{H}$ NMR (CD $3 \mathrm{OD}, 500 \mathrm{MHz}) \delta$ (ppm): 3.11 (broad t, $J 5.21 \mathrm{~Hz}, 4 \mathrm{H},-\mathrm{N}-\mathrm{CH}_{2}-\mathrm{CH}_{2}-\mathrm{N}-$ ); 3.21 (broad t, $\left.J 5 \mathrm{~Hz}, 4 \mathrm{H},-\mathrm{N}-\mathrm{CH}_{2}-\mathrm{CH}_{2}-\mathrm{N}-\right) ; 3.62\left(\mathrm{~s}, 4 \mathrm{H},-\mathrm{N}-\mathrm{CH}_{2}-\mathrm{N}-\right) ; 4.12\left(\mathrm{~s}, 4 \mathrm{H},-\mathrm{CH}_{2}-\mathrm{CO}_{2} \mathrm{tBu}\right) ; 7.25(\mathrm{~d}, J$ $7.71 \mathrm{~Hz}, 2 \mathrm{H}, \mathrm{CH}=\mathrm{CH}-\mathrm{CH}=) ; .79(\mathrm{t}, J 7.7 \mathrm{~Hz}, 1 \mathrm{H},-\mathrm{CH}=\mathrm{CH}-\mathrm{CH}=)$.

2-(12-\{[(2-aminoethyl)carbamoyl $]$ methoxy $\}-9-($ carboxymethyl)-3,6,9,15tetraazabicyclo[9.3.1]pentadeca-1(15),11,13-trien-3-yl)acetic acid manganese compound 11a: A solution of $\mathrm{MnCl}_{2} .4 \mathrm{H}_{2} \mathrm{O}(7 \mathrm{mg}, 0.035 \mathrm{mmol})$ in water $(0.5 \mathrm{~mL})$ is added dropwise to a solution of compound 10a $(12 \mathrm{mg}, 0.018 \mathrm{mmol})$ in water $(1 \mathrm{~mL})$. The $\mathrm{pH}$ is adjusted and maintained to $5<\mathrm{pH}<6$ with $0.1 \mathrm{M}$ aqueous solution of $\mathrm{NaOH}$. The mixture is warmed at $40^{\circ} \mathrm{C}$ overnight. The presence of free $\mathrm{Mn}^{2+}$ is revealed by the colorimetric test with orange xylenol. The aqueous mixture is treated with Chelex resin, then freeze-dried to give the desired compound 11a. ESI$\operatorname{MS}\left(\mathrm{C}_{15} \mathrm{H}_{20} \mathrm{MnN}_{4} \mathrm{O}_{4}\right): \mathrm{m} / \mathrm{z} 398.09[\mathrm{M}+\mathrm{Na}]^{+}$.

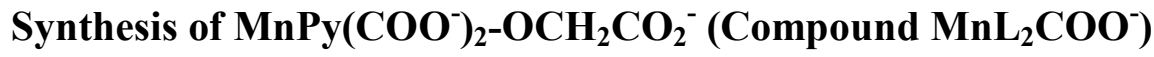

Benzyl 3,9-bis(2-tert-butoxy-2-oxo-ethyl)-12-(2-ethoxy-2-oxo-ethoxy)-3,6,9,15tetrazabicyclo[9.3.1]pentadeca-1(14),11(15),12-triene-6-carboxylate compound $\quad 7 \boldsymbol{b}$ : Solid $\mathrm{Na}_{2} \mathrm{CO}_{3}(466 \mathrm{mg}, 4.40 \mathrm{mmol}, 4 \mathrm{eq})$ is added to a solution of triamine lower part $\mathbf{5 b}$ (513 $\mathrm{mg}$, $1.10 \mathrm{mmol})$ with dibromomethyl compound $\mathbf{6 b}(444 \mathrm{mg}, 1.21 \mathrm{mmol}, 1.1 \mathrm{eq})$ in acetonitrile $(110 \mathrm{~mL})$. The suspension is refluxed until completion of the reaction (MS and/or TLC 
monitoring; 1 hour). The insoluble matter is filtered off, and the filtrate is concentrated to dryness. The crude material obtained is purified by chromatography on silica gel $\left(\mathrm{CH}_{2} \mathrm{Cl}_{2} / \mathrm{MeOH}, 100 / 0\right.$ to $\left.98 / 2 v / v\right)$ to give the desired compound $7 \mathbf{b}$ as a thick oil (471 mg, $0.702 \mathrm{mmol})$. Yield 64\%. ${ }^{1} \mathrm{H}$ NMR $\left(\mathrm{CDCl}_{3}, 400 \mathrm{MHz}\right) \delta(\mathrm{ppm}): 1.27$ (t, 3H, J 7.1 Hz, -Et); 1.45 (s, 9H, -tBu); 1.48 (s, 9H, -tBu); 2.68-3.01 (m, 4H, -N-CH $\left.\mathrm{CH}_{2}-\mathrm{CH}_{2}-\mathrm{N}-\right)$; 3.20-3.55 (m, 8H, -N-CH ${ }_{2}^{-}$ $\mathrm{CH}_{2}-\mathrm{N}-(4 \mathrm{H})$ and $\left.-\mathrm{N}-\mathrm{CH}_{2}-\right) ; 3.95$ (d, 2H, J $10.2 \mathrm{~Hz},-\mathrm{N}-\mathrm{CH}_{2}-$ ); 4.19 (d, 2H, J 7.3 Hz, -N-CH $2^{-}$); $4.24(\mathrm{~d}, 2 \mathrm{H}, J 7.1 \mathrm{~Hz},-\mathrm{Et}) ; 4.66\left(\mathrm{~s}, 2 \mathrm{H},-\mathrm{O}-\mathrm{CH}_{2}-\mathrm{CO}_{2}-\mathrm{Et}\right) ; 5.04$ (s, 2H, $\left.-\mathrm{CH}_{2}-\mathrm{Ph}\right) ; 7.04$ (d, $\left.J 8.4 \mathrm{~Hz}, 1 \mathrm{H},-\mathrm{CH}_{2}-\mathrm{C}(\mathrm{N})-\mathrm{CH}=\mathrm{CH}-\mathrm{C}(\mathrm{OR})-\mathrm{C}\right) ; 7.18\left(\right.$ broad dd, ${ }^{\mathfrak{f}}{ }^{4} J \approx^{3} J 8.4 \mathrm{~Hz}, 1 \mathrm{H},-\mathrm{CH}_{2}-\mathrm{C}(\mathrm{N})-$ $\mathrm{CH}=\mathrm{CH}-\mathrm{C}(\mathrm{OR})-\mathrm{C}) ;$ 7.24-7.37 (m, 5H, -Ph). ${ }^{£ \mathfrak{T}}$ That resonance looks like a broad unsymmetrical triplet that can be attributed to a doublet of doublet with similar ${ }^{3} J(8.4 \mathrm{~Hz}$, vicinal coupling) and ${ }^{4} J$ coupling constants; the unusually high long-range ${ }^{4} J$ coupling constant $(\approx 8.4 \mathrm{~Hz})$ may be due to a pseudo W-conformation of the four sigma bonds between the two coupled ${ }^{1} \mathrm{H} .{ }^{13} \mathrm{C}$ NMR $\left(\mathrm{CDCl}_{3}, 100 \mathrm{MHz}\right) \delta(\mathrm{ppm})$ : Caution: Some of the ${ }^{13} \mathrm{C}$ are doublet due to the presence of rotamers. $14.2\left(\mathrm{CH}_{3} \_\mathrm{Et}\right) ; 28.3\left(\mathrm{CH}_{3} 2 \mathrm{2}-\mathrm{tBu}\right) ; 44.6,45.0,45.5,46.1^{\$ \$}\left(2-\mathrm{N}-\mathrm{CH}_{2}-\mathrm{CH}_{2}-\mathrm{N}-\right) ; 51.3$, $51.8,52.0,52.4^{\$ \$}\left(2-\mathrm{N}-\mathrm{CH}_{2}-\mathrm{CH}_{2}-\mathrm{N}-\right) ; 54.5,54.6^{\$}\left(-\mathrm{N}-\mathrm{CH}_{2}-\right) ; 58.7,58.9,59.5\left(3-\mathrm{N}-\mathrm{CH}_{2}-\right) ; 61.6$ $\left(\mathrm{CH}_{2} \mathrm{Et}\right) ; 65.8\left(-\mathrm{O}-\mathrm{CH}_{2}-\mathrm{CO}_{2}-\mathrm{Et}\right) ; 66.8 \quad\left(-\mathrm{CH}_{2}-\mathrm{Ph}\right) ; 81.0,81.2 \quad\left(2 \mathrm{C}_{\text {quat }} \mathrm{tBu}\right) ; 119.8, \quad 119.9^{\$}$ $\left(\mathrm{CH}_{\mathrm{Ar}} \mathrm{Pyr}\right) ; 123.8\left(\mathrm{CH}_{\mathrm{Ar}} \mathrm{Pyr}\right) ; 127.6,127.8,128.5\left(3 \mathrm{CH}_{\mathrm{Ar}} \mathrm{Ph}\right) ; 137.1\left(\mathrm{C}_{\text {quat }} \mathrm{Ph}\right) ; 147.6,151.8^{£}$, $156.2\left(\mathrm{NCO}_{2}\right.$, and $\left.3 \mathrm{C}_{\text {quat }} \mathrm{Pyr}\right) ; 166.4,168.3,170.7-170.9^{\&}\left(3 \mathrm{CO}_{2}\right) .{ }^{\$}$ Double signal for the assigned ${ }^{13} \mathrm{C}$ (rotamers); ${ }^{\$ \$}$ Double signal for each of the assigned ${ }^{13} \mathrm{C}$; ${ }^{\&}$ Broad and small signal; ${ }^{£}$ Higher signal than the adjacent one; may account for several ${ }^{13} \mathrm{C}$.

Ethyl 2-(\{3,9-bis[2-(tert-butoxy)-2-oxoethyl]-3,6,9,15-tetraazabicyclo[9.3.1] pentadeca1(15),11,13-trien-12-yl \}oxy)acetate compound $8 \boldsymbol{b}$ : Compound $7 \mathbf{b}$ (55 mg, $0.082 \mathrm{mmol}, 1 \mathrm{eq})$ is 
solubilized in $\mathrm{MeOH}(20 \mathrm{~mL})$ followed by the addition of $\mathrm{Pd} / \mathrm{C}(6 \mathrm{mg})$. The solution is placed under $\mathrm{H}_{2}$ at atmospheric pressure and is stirred during $24 \mathrm{~h}$. Insoluble material is filtered through Celite $^{\circledR}$ and the filtrate is concentrated at relatively high temperature to eliminate the toluene which is the by-product to give the desired compound $\mathbf{8 b}$. The crude product is directly engaged in the next synthesis step. ${ }^{1} \mathrm{H}$ NMR $\left(\mathrm{CD}_{3} \mathrm{OD}, 500 \mathrm{MHz}\right) \delta(\mathrm{ppm}): 1.28\left(\mathrm{t}, J 7.15 \mathrm{~Hz}, 3 \mathrm{H},-\mathrm{CH}_{2}\right.$ $\left.\mathrm{CH}_{3}\right) ; 1.46(\mathrm{~s}, 9 \mathrm{H},-\mathrm{tBu}) ; 1.47(\mathrm{~s}, 9 \mathrm{H},-\mathrm{tBu}) ; 3.07-3.12\left(\mathrm{~m}, 4 \mathrm{H},-\mathrm{N}-\mathrm{CH}_{2}-\mathrm{CH}_{2}-\mathrm{N}-\right)$; 3.16-3.21 (m,

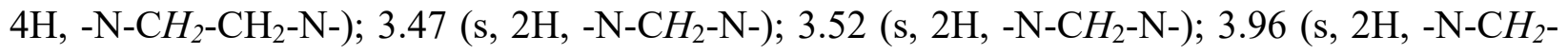
CO-); 4.17 (s, 2H, -N-CH$\left.{ }_{2}-\mathrm{CO}-\right)$; 4.23 (q, J $7.11 \mathrm{~Hz}, 2 \mathrm{H},-\mathrm{O}-\mathrm{CH}_{2}-\mathrm{CH}_{3}$ ); 4.82 (s, 2H, -O-CH $2_{2}^{-}$ CO-); 7.11 (d, J $8.42 \mathrm{~Hz}, 1 \mathrm{H},-\mathrm{O}-\mathrm{C}=\mathrm{CH}-\mathrm{CH}=\mathrm{C}-)$; 7.27 (d, 1H, J 8.43 Hz, -O-C=CH-CH=C-).

2-(\{3,9-Bis[2-(tert-butoxy)-2-oxoethyl]-3,6,9,15-tetraazabicyclo[9.3.1]pentadeca-1(15),11,13trien-12-yl \}oxy)acetic acid compound 9: Compound $\mathbf{8 b}$ (481 mg, $0.90 \mathrm{mmol}$, 1eq) is solubilized in ethanol $(7 \mathrm{~mL})$ and put under stirring. A solution of aqueous $1 \mathrm{M} \mathrm{NaOH}$ is then added $(1 \mathrm{~mL}, 1$ mmol, $1.1 \mathrm{eq})$. The solution is stirred during few hours, then concentrated under vacuum. The crude product is purified by flash chromatography on RP18 column $\left(\mathrm{MeOH} / \mathrm{H}_{2} \mathrm{O}\right.$ from $3 / 7$ to $10 / 0 \mathrm{v} / \mathrm{v})$ to give the desired compound 9 (310 $\mathrm{mg}, 0.61 \mathrm{mmol}$ ). Yield 67\% (determined by weighing). ${ }^{1} \mathrm{H}$ NMR $\left(\mathrm{CD}_{3} \mathrm{OD}, 500 \mathrm{MHz}\right) \delta(\mathrm{ppm}): 1.47$ (s, 9H, -tBu); $1.47(\mathrm{~s}, 9 \mathrm{H},-t B u) ; 2.99$ 3.06 (m, 4H, -N-CH $\left.2-\mathrm{CH}_{2}-\mathrm{N}-\right)$; 3.11-3.16 (m, 4H, -N-CH $\left.-\mathrm{CH}_{2}-\mathrm{N}-\right)$; 3.26 (s, 2H, -N-CH $\left.-\mathrm{N}-\right)$; 3.53 (s, 2H, -N-CH${ }_{2}-\mathrm{N}-$ ); 3.94 (s, 2H, -N-CH$\left.{ }_{2}-\mathrm{CO}-\right)$; 4.18 (s, 2H, -N-CH$H_{2}-\mathrm{CO}-$ ); 4.46 (s, 2H, -O$\left.\mathrm{CH}_{2}-\mathrm{CO}-\right)$; 7.05 (d, $\left.1 \mathrm{H}, J 8.41 \mathrm{~Hz},-\mathrm{O}-\mathrm{C}=\mathrm{CH}-\mathrm{CH}=\mathrm{C}\right) ; 7.11(\mathrm{~d}, J 8.41 \mathrm{~Hz}, 1 \mathrm{H},-\mathrm{O}-\mathrm{C}=\mathrm{C} H-\mathrm{CH}=\mathrm{C})$.

2-\{[3,9-Bis(carboxymethyl)-3,6,9,15-tetraazabicyclo[9.3.1]pentadeca-1(15),11,13-trien-12yl]oxy acetic acid $\mathbf{1 0 b}$ : The compound $9(10 \mathrm{mg}, 0.019 \mathrm{mmol})$ is solubilized in dichloromethane 
$(1 \mathrm{~mL})$ and put under stirring followed by the addition of trifluoroacetic acid $(1 \mathrm{~mL})$. The solution is stirred overnight. It is then concentrated and washed two times with diethyl ether (4 $\mathrm{mL}$ ) to give the desired compound $\mathbf{1 0 b}$ as TFA salt. The crude product is directly engaged in the next synthesis step. ${ }^{1} \mathrm{H}$ NMR $\left(\mathrm{CD}_{3} \mathrm{OD}, 500 \mathrm{MHz}\right) \delta$ (ppm): 3.08-3.14 (broad s, 4H, -N-CH $\mathrm{C}_{2}-\mathrm{CH}_{2^{-}}$ N-); 3.18-3.26 (broad m, 4H, -N-CH$-\mathrm{CH}_{2}-\mathrm{N}-$ ); 3.62 (s, 2H, -N-CH2-N-); 3.69 (s, 2H, -N-CH ${ }_{2}^{-}$ $\mathrm{N}-) ; 4.06\left(\mathrm{~s}, 2 \mathrm{H},-\mathrm{N}-\mathrm{CH}_{2}-\mathrm{CO}_{2} \mathrm{H}\right) ; 4.27\left(\mathrm{~s}, 2 \mathrm{H},-\mathrm{N}-\mathrm{CH}_{2}-\mathrm{CO}_{2} \mathrm{H}\right) ; 4.82\left(\mathrm{~s}, 2 \mathrm{H},-\mathrm{O}-\mathrm{CH}_{2}-\mathrm{CO}_{2} \mathrm{H}\right) ; 7.19$ $(\mathrm{d}, 1 \mathrm{H}, J 8.29 \mathrm{~Hz},-\mathrm{O}-\mathrm{C}=\mathrm{CH}-\mathrm{CH}=\mathrm{C}-)$; $7.34(\mathrm{~d}, 1 \mathrm{H}, J 8.43 \mathrm{~Hz},-\mathrm{O}-\mathrm{C}=\mathrm{CH}-\mathrm{CH}=\mathrm{C}-)$.

2-(12-\{[(2-aminoethyl)carbamoyl]methoxy $\}-9-($ carboxymethyl)-3,6,9,15-

tetraazabicyclo[9.3.1]pentadeca-1(15),11,13-trien-3-yl)acetic acid manganese compound 11b: A solution of $\mathrm{MnCl}_{2} .4 \mathrm{H}_{2} \mathrm{O}(6 \mathrm{mg}, 0.03 \mathrm{mmol})$ in water $(0.5 \mathrm{~mL})$ is added dropwise to a solution of compound $10 \mathrm{~b}(11 \mathrm{mg}, 0.016 \mathrm{mmol})$ in water $(1 \mathrm{~mL})$. The $\mathrm{pH}$ is adjusted and maintained to $5<\mathrm{pH}<6$ with $0.1 \mathrm{M}$ aqueous solution of $\mathrm{NaOH}$. The mixture is warmed at $40^{\circ} \mathrm{C}$ overnight. The presence of free $\mathrm{Mn}^{2+}$ is revealed by the colorimetric test with orange xylenol. The aqueous mixture is treated with Chelex resin, then freeze-dried to give the desired compound 11b. ESI$\operatorname{MS}\left(\mathrm{C}_{17} \mathrm{H}_{22} \mathrm{MnN}_{4} \mathrm{O}_{7}\right): \mathrm{m} / \mathrm{z} 472.10[\mathrm{M}+\mathrm{Na}]^{+}$.

\section{Synthesis of $\mathrm{MnPy}\left(\mathrm{COO}^{-}\right)_{2}-\mathrm{OCH}_{2} \mathrm{CO}_{2} \mathrm{NHCH}_{2} \mathrm{CCH}\left(\mathrm{Compound} \mathrm{MnL}_{3} \mathrm{CH}\right)$}

Tert-butyl 2-\{9-[2-(tert-butoxy)-2-oxoethyl]-12-\{[(prop-2-yn-1-yl)carbamoyl] methoxy $\}-$ 3,6,9,15-tetraazabicyclo[9.3.1]pentadeca-1(15),11,13-trien-3-yl\}acetate compound 12: Compound 9 (10 mg, $0.019 \mathrm{mmol})$ and HBTU (15 mg, $0.04 \mathrm{mmol}, 2.1 \mathrm{eq})$ are solubilized in $\mathrm{CH}_{2} \mathrm{Cl}_{2}(2 \mathrm{~mL})$ followed by the addition of propargylamine $(2 \mu \mathrm{L}, 0.031 \mathrm{mmol}, 1.6 \mathrm{eq})$ and DIPEA ( $8 \mu \mathrm{L}, 0.047 \mathrm{mmol}, 2.47 \mathrm{eq})$. The solution is stirred during few hours at room 
temperature then the middle is washed three times with water $(5 \mathrm{~mL})$ to give the desired compound. Yield (crude) $>90 \%$ (determined by weighing). The crude product is directly engaged in the next synthesis step. ${ }^{1} \mathrm{H}$ NMR $\left(\mathrm{CDCl}_{3}, 500 \mathrm{MHz}\right) \delta(\mathrm{ppm}): 1.45(\mathrm{~s}, 18 \mathrm{H},-t B u) 2.22(\mathrm{t}, J$ $2.56 \mathrm{~Hz}, 1 \mathrm{H},-\mathrm{C} \equiv \mathrm{CH}) ; 3.03-3.11\left(\mathrm{~m}, 4 \mathrm{H},-\mathrm{N}-\mathrm{CH}_{2}-\mathrm{CH}_{2}-\mathrm{NH}-\right)$; 3.21-3.28 (m, 4H, -N-CH $2_{2}-\mathrm{CH}_{2}-$ $\mathrm{NH}) ; 3.43$ (s, 2H, -C-CH$-\mathrm{N}-$ ); 3.47 (s, 2H, -C-CH2 $-\mathrm{N}-$ ); 3.92 (s, 2H, -N-CH$H_{2}-\mathrm{CO}-$ ); 4.08-4.16 (m, 4H, -N-CH$H_{2} \mathrm{CO}-$ and -NH-CH$H_{2}-\mathrm{C}-$ ); 4.54 (s, 2H, -O-CH2-CO-); 7.02 (d, J 8.39 Hz, 1H, -O$\mathrm{C}=\mathrm{CH}-\mathrm{CH}=\mathrm{C}-) ; 7.07$ (d, J 8.39 Hz, $1 \mathrm{H},-\mathrm{O}-\mathrm{C}=\mathrm{CH}-\mathrm{CH}=\mathrm{C}-)$.

2-[9-(Carboxymethyl)-12-\{[(prop-2-yn-1-yl)carbamoyl]methoxy $\}-3,6,9,15-$ tetraazabicyclo[9.3.1]pentadeca-1(15),11,13-trien-3-yl]acetic acid compound 13: Compound 12 (119 mg, $0.218 \mathrm{mmol}$ ) is solubilized in $\mathrm{CH}_{2} \mathrm{Cl}_{2}(3 \mathrm{~mL})$ and stirred followed by the addition of trifluoroacetic acid $(3 \mathrm{~mL})$. Overnight, the solution is concentrated and washed two times with diethyl ether to give the desired compound $\mathbf{1 3}$ as TFA salt. The crude product is directly engaged in the next synthesis step. ${ }^{1} \mathrm{H}$ NMR $\left(\mathrm{CD}_{3} \mathrm{OD}, 500 \mathrm{MHz}\right) \delta(\mathrm{ppm}): 2.60(\mathrm{t}, J 2.54 \mathrm{~Hz}, 1 \mathrm{H}$, $\mathrm{C} \equiv \mathrm{CH}) ; 3.10-3.16\left(\mathrm{~m}, 4 \mathrm{H}, \mathrm{N}-\mathrm{CH}_{2}-\mathrm{CH}_{2}-\mathrm{NH}-\right)$; 3.19-3.25 (m, 2H, N-CH $\left.\mathrm{CH}_{2}-\mathrm{NH}-\right)$; 3.25-3.30 (m, 2H, N-CH ${ }_{2}-\mathrm{CH}_{2}-\mathrm{NH}-$ ); 3.69 (s, 2H, -N-CH$\left.{ }_{2}-\mathrm{C}-\right) ; 3.80$ (s, 2H, -N-CH2-C-); 4.03 (d, J 2.56 $\left.\mathrm{Hz}, 2 \mathrm{H},-\mathrm{NH}-\mathrm{CH}_{2}-\mathrm{C}\right) ; 4.15$ (s, 2H, -N-CH$\left.{ }_{2}-\mathrm{COOH}\right) ; 4.38$ (s, 2H, -N-CH$\left.{ }_{2}-\mathrm{COOH}\right) ; 4.71$ (s, 2H, $\left.\mathrm{O}-\mathrm{CH}_{2}-\mathrm{CO}-\right) ; 7.28$ (d, J $\left.8.49 \mathrm{~Hz}, 1 \mathrm{H},-\mathrm{O}-\mathrm{C}=\mathrm{CH}-\mathrm{CH}=\mathrm{C}-\right) ; 7.41(\mathrm{~d}, J 8.49 \mathrm{~Hz}, 1 \mathrm{H},-\mathrm{O}-\mathrm{C}=\mathrm{CH}-$ $\mathrm{CH}=\mathrm{C}-$ ).

2-(12-\{[(2-Aminoethyl)carbamoyl]methoxy $\}-9-($ carboxymethyl)-3,6,9,15tetraazabicyclo[9.3.1]pentadeca-1(15),11,13-trien-3-yl)acetic acid manganese compound 14: A solution of $\mathrm{MnCl}_{2} .4 \mathrm{H}_{2} \mathrm{O}(4 \mathrm{mg}, 0.02 \mathrm{mmol})$ in water $(0.5 \mathrm{~mL})$ is added dropwise to a solution of 
compound $13(8 \mathrm{mg}, 0.01 \mathrm{mmol})$ in water $(1 \mathrm{~mL})$. The $\mathrm{pH}$ is adjusted and maintained to $5<$ $\mathrm{pH}<6$ with $0.1 \mathrm{M}$ aqueous solution of $\mathrm{NaOH}$. The mixture is warmed at $40^{\circ} \mathrm{C}$ overnight. The presence of free $\mathrm{Mn}^{2+}$ ions is revealed by the colorimetric test with orange xylenol. The aqueous mixture is treated with Chelex resin, then freeze-dried to give the desired compound 14. ESI-MS $\left(\mathrm{C}_{20} \mathrm{H}_{25} \mathrm{MnN}_{5} \mathrm{O}_{6}\right): \mathrm{m} / \mathrm{z} 509.14[\mathrm{M}+\mathrm{Na}]^{+}$.

\section{Synthesis of $\mathrm{MnPy}\left(\mathrm{COO}^{-}\right)_{2}-\mathrm{OCH}_{2} \mathrm{CO}_{2} \mathrm{NHCH}_{2} \mathrm{CH}_{2} \mathrm{NH}_{2}\left(\mathrm{Compound} \mathrm{MnL}_{4} \mathrm{NH}_{3}{ }^{+}\right)$}

Benzyl 12-[2-(2-aminoethylamino)-2-oxo-ethoxy]-3,9-bis(2-tert-butoxy-2-oxo-ethyl)-3,6,9,15tetrazabicyclo[9.3.1]pentadeca-1(14),11(15),12-triene-6-carboxylate compound 15: A solution of the previously prepared ethyl ester $7 \mathbf{b}(470 \mathrm{mg}, 701 \mathrm{mmol})$ in ethylenediamine $(2.3 \mathrm{~mL}$, $34.4 \mathrm{mmol}, 50 \mathrm{eq}$ ) is stirred at room temperature until completion of the reaction (MS monitoring; 1 hour). The crude medium is diluted in $\mathrm{CH}_{2} \mathrm{Cl}_{2}(15 \mathrm{~mL})$ and is washed with water $(3 \mathrm{~mL})$. The organic layer is dried then concentrated to dryness. The resulting material is purified by chromatography on silica gel $\left(\mathrm{CH}_{2} \mathrm{Cl}_{2} / \mathrm{MeOH} / \mathrm{NH}_{3} 7 \mathrm{~N}\right.$ in $\mathrm{MeOH} 95 / 2.5 / 2.5$ to $90 / 5 / 5$ v/v/v) and led to the desired product 15 as a beige solid (279 mg, $0.407 \mathrm{mmol})$. Yield $58 \%$. ${ }^{1} \mathrm{H}$ NMR $\left(\mathrm{CDCl}_{3}, 400 \mathrm{MHz}\right) \delta(\mathrm{ppm}): 1.34-1.53(\mathrm{~m}, 18 \mathrm{H},-\mathrm{tBu}) ; 1.94\left(\right.$ broad s, $\left.2 \mathrm{H},-\mathrm{NH}_{2}\right) ; 2.55-2.66(\mathrm{~m}$, $\left.2 \mathrm{H},-\mathrm{N}-\mathrm{CH}_{2}-\mathrm{CH}_{2}-\mathrm{N}-\right) ; 2.66-2.88\left(\mathrm{~m}, 4 \mathrm{H},-\mathrm{N}-\mathrm{CH}_{2}-\mathrm{CH}_{2}-\mathrm{N}(2 \mathrm{H})\right.$ and $\left.-\mathrm{CH}_{2}-\mathrm{NH}_{2}\right) ; 2.96-3.09$ (m, $2 \mathrm{H}$, $\left.-\mathrm{N}-\mathrm{CH}_{2}-\mathrm{CH}_{2}-\mathrm{N}-\right)$; 3.28-3.50 (m, 8H, -CO-NH-CH $\left.2_{2}^{-},-\mathrm{N}-\mathrm{CH}_{2}-(4 \mathrm{H}),-\mathrm{N}_{-} \mathrm{CH}_{2}-\mathrm{CH}_{2}-\mathrm{N}-(2 \mathrm{H})\right) ; 3.89$ and $3.93\left(2\right.$ br s$\left.^{\$}, 2 \mathrm{H},-\mathrm{N}-\mathrm{CH}_{2^{-}}\right)$; 4.02 and 4.05 (2 br s$\left.\$, 2 \mathrm{H},-\mathrm{N}-\mathrm{CH}_{2^{-}}\right)$; 4.56 (broad s, 2H, -O$\left.\mathrm{CH}_{2^{-}}\right) ; 5.01\left(\mathrm{~s}, 2 \mathrm{H},-\mathrm{CH}_{2}-\mathrm{Ph}\right) ; 7.16\left(\mathrm{~d}, J 8.4 \mathrm{~Hz}, 1 \mathrm{H},-\mathrm{CH}_{2}-\mathrm{C}(\mathrm{N})-\mathrm{CH}=\mathrm{CH}-\mathrm{C}(\mathrm{OR})-\mathrm{C}\right) ; 7.21-7.33$ 
$\left(\mathrm{m}, 6 \mathrm{H},-\mathrm{CH}_{2}-\mathrm{C}(\mathrm{N})-\mathrm{CH}=\mathrm{CH}-\mathrm{C}(\mathrm{OR})-\mathrm{C}\right.$, and $\left.\mathrm{Ph}\right) ; 8.15$, and $8.25^{\$}(2$ broad $\mathrm{t}, 1 \mathrm{H}(\approx 53 / 47)$, $-\mathrm{CO}-$ $\mathrm{NH}-$ ). ${ }^{\$}$ Double signal due to two conformers (double-bond character of the amide bond: cis and trans conformations) or two rotamers (free rotation obstruction due to $\mathrm{Cbz}$ steric hindrance). ${ }^{13} \mathrm{C} \mathrm{NMR}\left(\mathrm{CDCl}_{3}, 100 \mathrm{MHz}\right) \delta(\mathrm{ppm})$ : Caution: As previously observed for the precursor $7 \mathrm{~b}$, nearly all of the ${ }^{13} \mathrm{C}$ are doublet due to the presence of rotamers (double bond character of the amide bond and/or free-rotation obstruction of the carbamate bond). 28.18, $28.23\left(\mathrm{CH}_{3} \_2-\mathrm{tBu}\right)$; 41.8, 42.1, 42.2, $42.3\left(-\mathrm{CO}-\mathrm{NH}-\mathrm{CH}_{2}-\mathrm{CH}_{2}-\mathrm{NH}_{2}\right)^{\#} ; 44.9,45.4\left(-\mathrm{N}-\mathrm{CH}_{2}-\mathrm{CH}_{2}-\mathrm{N}-\right)^{\#} ; 50.9,51.0,51.6$, $51.8\left(2-\mathrm{N}-\mathrm{CH}_{2}-\mathrm{CH}_{2}-\mathrm{N}-\right)^{\#} ; 54.2,54.5\left(-\mathrm{N}-\mathrm{CH}_{2}-\right)^{\#} ; 58.8,59.0,59.1,59.4\left(-\mathrm{N}_{-} \mathrm{CH}_{2}-\mathrm{CH}_{2}-\mathrm{N}-\right.$, and $3-$ $\left.\mathrm{N}-\mathrm{CH}_{2-}\right) ; 66.9\left(-\mathrm{CH}_{2}-\mathrm{Ph}\right) ; 67.2\left(-\mathrm{O}-\mathrm{CH}_{2}-\right) ; 81.2,81.47,81.52\left(2 \mathrm{C}_{\text {quat }} \mathrm{tBu}\right)^{\$} ; 119.65,119.68(-$ $\left.\mathrm{CH}_{2}-\mathrm{C}(\mathrm{N})-\mathrm{CH}=\mathrm{CH}-\mathrm{C}(\mathrm{OR})-\mathrm{C}\right)^{\#} ; \quad 124.97, \quad 125.01 \quad\left(-\mathrm{CH}_{2}-\mathrm{C}(\mathrm{N})-\mathrm{CH}=\mathrm{CH}-\mathrm{C}(\mathrm{OR})-\mathrm{C}\right)^{\#} ; \quad 127.57$, 127.65, 127.83, 127.90, $128.46\left(3 \mathrm{CH}_{\mathrm{Ar}} \mathrm{Ph}\right)^{\$} ; 136.85,136.94\left(\mathrm{C}_{\text {quat }} \mathrm{Ph}\right)^{\#} ; 145.9,146.1,149.2$, $149.7,151.7,151.8,155.9,156.0\left(-\mathrm{N}-\mathrm{CO}_{2} \text {, and } 3 \mathrm{C}_{\text {quat }} \mathrm{Pyr}\right)^{\#} ; 168.21,168.24,170.4,170.6,170.7$, $170.8\left(2 \mathrm{CO}_{2} \text {, and } \mathrm{CONH}\right)^{\#}$. ${ }^{\#}$ Double signal for (each of) the assigned ${ }^{13} \mathrm{C}$ (rotamers); ${ }^{\$}$ Double signal for at least one of the assigned ${ }^{13} \mathrm{C}$.

2-(12-\{[(2-Aminoethyl)carbamoyl]methoxy $\}-9-($ carboxymethyl)-3,6,9,15tetraazabicyclo[9.3.1]pentadeca-1(15),11,13-trien-3-yl)acetic acid compound 16a.xHBr: A concentrated solution of the fully protected precursor 15 previously prepared (210 mg, $0.307 \mathrm{mmol})$ in $\mathrm{CH}_{2} \mathrm{Cl}_{2}(0.250 \mathrm{~mL})$ is diluted in acetic acid $(2 \mathrm{~mL})$. A solution of hydrogen bromide in acetic acid $(33 \% w / w, 0.500 \mathrm{~mL})$ is then added and a white precipitate appeared instantly. The mixture is vigorously stirred and heated at $70^{\circ} \mathrm{C}$ for 7 hours and then at room temperature overnight. The dark orange supernatant is removed by suction and the solid material is washed several times with $\mathrm{Et}_{2} \mathrm{O}$ until a clear wash is obtained. The organic solvents are 
completely removed first under reduced pressure and then by freeze-drying after solubilization in water to give the desired compound as a brownish solid material $(200 \mathrm{mg}, 0.288 \mathrm{mmol}$ on the basis on an estimated $\mathrm{PM} 693.38$ for $3 \mathrm{HBr} / 4 \mathrm{HBr}$ hydrobromide forms in $85 / 15 \mathrm{~mol} / \mathrm{mol}$ at $p H 0.7^{47}$ ). Yield (crude) 94\%. The crude material can be purified by chromatography on RP18 $\left(\mathrm{CH}_{3} \mathrm{CN} / \mathrm{H}_{2} \mathrm{O} 9 / 1 \mathrm{v} / \mathrm{v}\right)$ after raising the $\mathrm{pH}$ from 0.7 to about $4.5\left(\mathrm{NaOH}_{\mathrm{aq}}\right)$ and leads to the desired product as a beige solid $(115 \mathrm{mg}, 0.221 \mathrm{mmol}$ on the basis on an estimated PM 516.97 for $.1 \mathrm{HBr} / .0 \mathrm{HBr} / .2 \mathrm{HBr}$ hydrobromide forms in $73 / 15 / 12 \mathrm{~mol} / \mathrm{mol} / \mathrm{mol}$ at $\mathrm{pH} 4.5^{47}$ ). Yield $72 \%$. ${ }^{1} \mathrm{H}$ NMR $\left(\mathrm{D}_{2} \mathrm{O}, p H<1\right) \delta(\mathrm{ppm}): 3.14$ (broad t, $2 \mathrm{H},-\mathrm{CH}_{2}-\mathrm{NH}_{2-}$ ); 3.20-3.38 (m, 6H, -N-CH $2^{-} \mathrm{CH}_{2^{-}}$ $\mathrm{NH}-$ ); 3.44 (broad s, 2H, -N-CH${ }_{2}-\mathrm{CH}_{2}-\mathrm{N}-$ ); 3.56 (broad t, 2H, -CO-NH-CH $2^{-}$); 4.00 (s, 2H, -N-

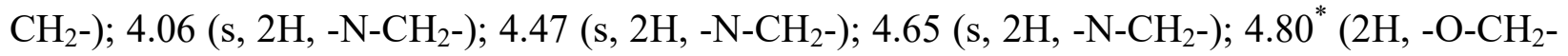
CO-N-); 7.57 (d of AB system, J $8.4 \mathrm{~Hz}, 1 \mathrm{H}, \mathrm{CH}_{\mathrm{Ar}}$ );7.71 (d of AB system, J $8.4 \mathrm{~Hz}, 1 \mathrm{H}, \mathrm{CH}_{\mathrm{Ar}}$ ). ${ }^{*}$ Fully superimposed with the deuterated solvent (deduced from corr ${ }^{1} \mathrm{H} /{ }^{13} \mathrm{C} 2 \mathrm{D}$ experiment). ${ }^{13} \mathrm{C}$ NMR $\left(\mathrm{D}_{2} \mathrm{O}, \mathrm{pH}<1\right)$ : 36.6 (-CO-NH-CH $\left.2^{-}\right) ; 39.0\left(-\mathrm{CH}_{2}-\mathrm{NH}_{2}-\right)$; 43.7, 43.9 (2 -N-CH$\left.{ }_{2}-\mathrm{CH}_{2}-\mathrm{NH}-\right)$;

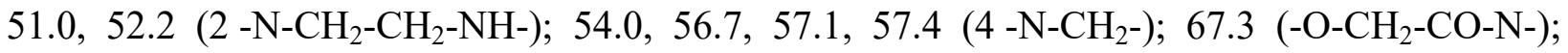
$125.0\left(2 \mathrm{CH}_{\mathrm{Ar}}\right) ; 142.1,144.3,152.0$ (3 $\left.\mathrm{C}_{\text {quat }} \mathrm{Pyr}\right)$; 170.6, 172.2, 172.3 (2 $\mathrm{CO}_{2}$, and -CO-NH-).

2-(12-\{[(2-aminoethyl)carbamoyl]methoxy $\}-9-($ carboxymethyl)-3,6,9,15-tetra azabicyclo[9.3.1]pentadeca-1(15),11,13-trien-3-yl)acetic acid manganese compound 17:

A solution of the previously prepared ligand 16a.xHBr $(\sim 0.17 \mathrm{mmol})$ in deionized $\mathrm{H}_{2} \mathrm{O}(3 \mathrm{~mL})$ is adjusted to $\mathrm{pH} \sim 5.5$ with an aqueous solution of $\mathrm{NaOH}$. Manganese(II) chloride tetrahydrate (33 mg, $0.168 \mathrm{mmol}$ ) is added in one portion which immediately induced a decrease of $p H$ down to 2.2 . The $\mathrm{pH}$ is carefully adjusted again to $\sim 5.7$ with aqueous $\mathrm{NaOH}$. The resulting mixture is stirred at room temperature for 5 minutes. A monitoring by MS indicated a total conversion to 
the desired manganese complex with no trace of free ligand 8 . The $\mathrm{pH}$ is then raised up to $\sim 7.5$ $\left(\mathrm{NaOH}_{\mathrm{aq}}\right)$ and stirring maintained overnight. The fine brown precipitate formed is filtered off over a $0.2 \mu \mathrm{m}$ membrane $\left(\mathrm{PALL}^{\circledR}\right.$, Acrodisc $\left.^{\circledR}\right)$. The filtrate is concentrated by freeze-drying. The solid obtained $(113 \mathrm{mg})$ is purified by chromatography on $\mathrm{RP} 18\left(\mathrm{MeOH} / \mathrm{H}_{2} \mathrm{O} 9 / 1 \mathrm{v} / v\right)$ and leads to the desired product $\mathbf{1 7}$ as a beige solid (108 mg, $\mathrm{x} \mathrm{H}_{2} \mathrm{O} . \mathrm{y} \mathrm{HCl}$ or $\mathrm{NaCl}$ probable form(s)). ESILRMS $m / z: 492.2[\mathrm{M}+\mathrm{H}]^{+}, 514.1[\mathrm{M}+\mathrm{Na}]^{+}$.

\section{Determination of $\mathrm{Mn}^{2+}$ concentration for relaxometric and ${ }^{17} \mathrm{O}$ measurements}

The detection of free manganese ions is performed with a test of xylenol orange: $300 \mu \mathrm{L}$ of phosphate or acetate buffer, one drop of pyridine, one drop of the compound solution and one drop of xylenol orange $(0.1 \mathrm{~g}$ per $100 \mathrm{~mL})$. The color is pink or orange for phosphate or acetate buffer respectively without manganese ions and gets purple when free manganese ions are present. The solution is then treated with a Chelex ${ }^{\circledR} 100$ resin (sodium form) to eliminate those free ions.

The $\mathrm{Mn}^{2+}$ concentration determination is performed either by relaxometry and ICP-AES, on samples digested with nitric acid. The first method consists in measuring the water paramagnetic longitudinal relaxation rate of the digested solution at $20 \mathrm{MHz}$. It is then compared to the paramagnetic relaxation rate of a $1 \mathrm{mM}$ solution of free manganese ions (equal to $8 \mathrm{~s}^{-1}$ at 20 $\mathrm{MHz}$ and $37^{\circ} \mathrm{C}$ ) in order to extract the manganese concentration. ${ }^{4}$ To ensure the results, ICPAES measurements are also performed on Varian Liberty Series II, based on a $\mathrm{Mn}^{2+}$ calibration curve. The concentrations obtained respectively from ICP-AES or relaxometry methods are 


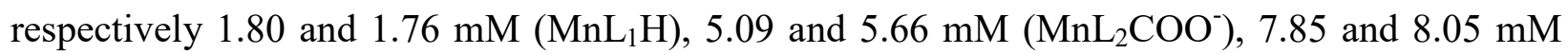

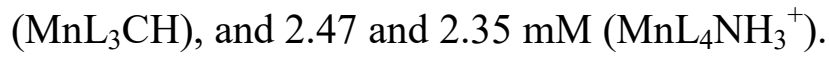

\section{Relaxometry measurement}

The longitudinal relaxation times $\left(\mathrm{T}_{1}\right)$ are determined at $20 \mathrm{MHz}$ and $60 \mathrm{MHz}$ on Bruker® Minispec mq20 and mq60 relaxometers. These measurements allow to obtain the relaxivity of the complexes according to the following equation $r_{1}=\frac{\left(\frac{1}{T_{1} 10^{-3}}\right)-R_{1}^{\mathrm{d}} \text { (water) }}{\left[\mathrm{Mn}_{\text {complex }}^{2+}\right]} \mathrm{s}^{-1} \cdot \mathrm{mM}^{-1}$ (3) where $R_{1 \text { (water) }}^{\mathrm{d}}=0.2826 \mathrm{~s}^{-1}$ at $37^{\circ} \mathrm{C}$.

The NMRD profiles were recorded at $37^{\circ} \mathrm{C}$ and $25^{\circ} \mathrm{C}$ on a Stelar ${ }^{\circledR}$ fast field cycling (FFC) relaxometer (Stelar, Mede, Italy) and the least-squares fitting of the data was performed using a home-made program (Fitting2000) and equations from the Solomon and Bloembergen (SBM) theory.

\section{Temperature dependent ${ }^{17} \mathrm{O}$ NMR measurements}

The transverse ${ }^{17} \mathrm{O}$ relaxation rates $\left(R_{2}=1 / T_{2}\right)$ are measured in aqueous solutions of each manganese complex $\left(\mathrm{MnL}_{1} \mathrm{H} ; 2.06 \mathrm{mM}, \mathrm{MnL}_{2} \mathrm{COO}^{-} ; 2.58 \mathrm{mM}, \mathrm{MnL}_{3} \mathrm{CH}: 2.05 \mathrm{mM}\right.$ and $\left.\mathrm{MnL}_{4} \mathrm{NH}_{3}{ }^{+}: 1.21 \mathrm{mM}\right)$ in the temperature range $7-81^{\circ} \mathrm{C}$, on a Bruker ${ }^{\circledR}$ AvanceII-500 $(11.75 \mathrm{~T}$, 67.8 MHz) spectrometer. The temperature is calculated according to a previous calibration with ethylene glycol and methanol. Proton decoupling is applied during all the acquisitions. Transverse relaxation times $\left(T_{2}\right)$ are obtained by the measurement of the signal width at midheight. For the determination of $\tau_{\mathrm{M}}$, the data are presented as the reduced transverse relaxation 
rate $R_{2}{ }^{\mathrm{R}}=1 / T_{2}{ }^{\mathrm{R}}=55.55 R_{2}{ }^{\mathrm{P}} /\left(\left[\mathrm{Mn}_{\text {complex }}\right] \cdot q\right)$, where $\left[\mathrm{Mn}_{\text {complex }}\right]$ is the molar concentration of the complex, $q$ is the number of coordinated water molecules and $R_{2}{ }^{\mathrm{P}}$ is the paramagnetic transverse relaxation rate obtained after subtraction of the diamagnetic contribution from the observed relaxation rate. The treatment of the experimental data is performed as already described and the fitting of the data is obtained with a home-made program. ${ }^{46}$

For the determination of the number of coordinated water molecules, the data are presented as the transverse relaxivity $r_{2}=R_{2}{ }^{\mathrm{P}} /\left[\mathrm{Mn}_{\text {complex }}\right]$ where the concentration of the $\mathrm{Mn}_{\text {complex }}$ is expressed in millimolar $\left(\mathrm{mmol} \cdot \mathrm{L}^{-1}\right)$.

\section{Transmetalation}

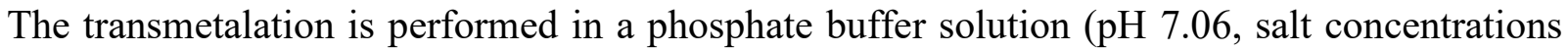
below) and on the Bruker ${ }^{\circledR}$ Minispec mq20 relaxometer. $300 \mu \mathrm{L}$ of a solution of each complex at a concentration of $2.5 \mathrm{mM}$ is prepared in phosphate buffer solution $\left(\left[\mathrm{NaH}_{2} \mathrm{PO}_{4}\right]=0.026 \mathrm{~mol} / \mathrm{L}\right.$ et $\left.\left[\mathrm{Na}_{2} \mathrm{HPO}_{4}\right]=0.041 \mathrm{~mol} / \mathrm{L}\right)$ and $3 \mu \mathrm{L}$ of a solution $250 \mathrm{mM}$ of $\mathrm{ZnCl}_{2}(1 \mathrm{eq})$ is added in the studied Mn-complexes solutions. Then, the longitudinal relaxation time $\left(T_{1}\right)$ is measured as a function of time to obtain the evolution of $R_{1}{ }^{\mathrm{p}}$ following the equation: $R_{1}^{\mathrm{p}}=\left(\frac{1}{T_{1} 10^{-3}}\right)-$ $R_{1 \text { (water) }}^{\mathrm{d}}$ (4) where $R_{1 \text { (water) }}^{\mathrm{d}}=0.2826 \mathrm{~s}^{-1}$ is the diamagnetic contribution. During 5 days, the ratio $R_{1}{ }^{\mathrm{p}} / R_{1}{ }^{\mathrm{p}}{ }_{(t=0)}$ is determined at regular intervals to evidence the transmetalation kinetics induced by the presence of zinc cations, which leads to a release of manganese ions and their precipitation by phosphates. This release induces formation of a precipitate of $\mathrm{Mn}_{3}\left(\mathrm{PO}_{4}\right)_{2}$, which leads to a decrease of the paramagnetic relaxation rate. ${ }^{41}$ 
Conflicts of interest

The authors declare no conflicts of interest

Acknowledgements

This work was performed with the financial support of SIRIC BRIO (COMMUCAN project https://siric-brio.com/commucan/), ARC the Walloon Region (Gadolymph, Prother-Wal and Interreg projects), FNRS, and the COST actions TD1004, TD1007, TD1402 and CM1006. The Bioprofiling platform, supported by the European Regional Development Fund and the Walloon Region, Belgium, is also acknowledged. Authors thank the Center for Microscopy and Molecular Imaging (CMMI, supported by European Regional Development Fund and Wallonia), Professor Gerbaux P., Dr De Winter J. and PhD student Weber P. from $\mathrm{S}^{2}$ Mos laboratory for the mass spectrometry analysis and Pierart C. for the NMRD measurements.

References and note

1. Washner, J., Gale, E. M., Rodrigez-Rodriguez, A. \& Caravan, P. Chemistry of MRI Contrast Agents: Current Challenges and New Frontiers. Chem. Rev. 119, 957-1057 (2019).

2. Grobner, T. \& Prischl, F. C. Gadolinium and nephrogenic systemic fibrosis. Kidney Int. 72, 260-264 (2007).

3. Beam, A. S., Moore, K. G., Gillis, S. N., Ford, K. F., Gray, T., Steinwinder, A. H. \& Graham, A. GBCAs and risk for nephrogenic systemic fibrosis: A literature review. 
Radiol. Technol. 88, 583-589 (2017).

4. Pan, D., Schmieder, A. H., Wickline, S. A. \& Lanza, G. M. Manganese-based MRI contrast agents: past, present and future. Tetrahedron 67, 8431-8444 (2011).

5. Botta, M., Carniato, F., Esteban-Gómez, D., Platas-Iglesias, C. \& Tei, L. Mn(II) compounds as an alternative to Gd-based MRI probes. Future Med. Chem. 11, 1461-1483 (2019).

6. Ramalho, J., Semelka, R. C., Ramalho, M., Nunes, R. H., AlObaidy, M. \& Castillo, M. Gadolinium-based contrast agent accumulation and toxicity: An update. Am. J. Neuroradiol. 37, 1192-1198 (2016).

7. Kanda, T., Fukusato, T., Matsuda, M., Toyoda, K., Oba, H., Kotoku, J., Haruyama, T., Kitajima, K. \& Furui, S. Gadolinium-based contrast agent accumulates in the brain even in subjects without severe renal dysfunction: Evaluation of autopsy brain specimens with inductively coupled plasma mass spectroscopy. Radiology 276, 228-232 (2015).

8. Gianolio, E., Gregorio, E. Di \& Aime, S. Chemical Insights into the Issues of Gd Retention in the Brain and Other Tissues Upon the Administration of Gd-Containing MRI Contrast Agents. Eur. J. Inorg. Chem. 2019, 137-151 (2019).

9. Robert, P., Lehericy, S., Grand, S., Violas, X., Fretellier, N., Ideé, J. M., Ballet, S. \& Corot, C. T1-Weighted Hypersignal in the Deep Cerebellar Nuclei after Repeated Administrations of Gadolinium-Based Contrast Agents in Healthy Rats: Difference between Linear and Macrocyclic Agents. Invest. Radiol. 50, 473-480 (2015).

10. Gianolio, E., Bardini, P., Arena, F., Stefania, R., Di Gregorio, E., Iani, R. \& Aime, S. 
Gadolinium Retention in the Rat Brain: Assessment of the Amounts of Insoluble Gadolinium-containing Species and Intact Gadolinium Complexes after Repeated Administration of Gadolinium-based Contrast Agents. Radiology 285, 839-849 (2017).

11. Drahoš, B., Lukeš, I. \& Tóth, É. Manganese ( II ) Complexes as Potential Contrast Agents for MRI. Eur. J. Inorg. Chem. 1975-1986 (2012) doi:10.1002/ejic.201101336.

12. Pan, D., Caruthers, S. D., Senpan, A., Schmieder, A. H., Wickline, S. A. \& Lanza, G. M. Revisiting an old friend: Mn-based MRI contrast agents. Wiley Interdiscip Rev Nanomed Nanobiotechnol. 3, 162-173 (2011).

13. Crossgrove, J. \& Zheng, W. Manganese toxicity upon overexposure. NMR Biomed. 17, 544-553 (2004).

14. O’Neal, S. L. \& Zheng, W. Manganese Toxicity Upon Overexposure: a Decade in Review. Curr Env. Heal. Rep. 2, 315-328 (2015).

15. Castets, C. R., Koonjoo, N., Hertanu, A., Voisin, P., Franconi, J. M., Miraux, S. \& Ribot, E. J. In vivo MEMRI characterization of brain metastases using a 3D Look-Locker T1mapping sequence. Sci. Rep. 6, 1-9 (2016).

16. Bianchi, A., Gobbo, O. L., Dufort, S., Sancey, L., Lux, F., Tillement, O., Coll, J. L. \& Crémillieux, Y. Orotracheal manganese-enhanced MRI (MEMRI): An effective approach for lung tumor detection. NMR Biomed. 30, 1-10 (2017).

17. Pierre, V. C., Allen, M. J. \& Caravan, P. Contrast agents for MRI: 30+ years and where are we going? J. Biol. Inorg. Chem. 19, 127-131 (2014).

18. Elizondo, G., Fretz, C. J., Stark, D. D., Rocklage, S. M., Quay, S. C., Worah, D., Tsang, 
D. D., Chia-Mei Chen, M. \& Ferrucci, J. T. Preclinical Evaluation of MnDPDP: New paramagnetic Hepatobiliary Contrast Agent for MR Imaging. Radiology 178, 73-78 (1991).

19. Laurent, S., Vander Elst, L. \& Muller, R. N. Comparative study of the physicochemical properties of six clinical low molecular weight gadolinium contrast agents. Contrast Media Mol. Imaging 1, 128-137 (2006).

20. Venter, A., Szulc, D. A., Loai, S., Ganesh, T., Haedicke, I. E. \& Cheng, H. L. M. A manganese porphyrin-based T1 contrast agent for cellular MR imaging of human embryonic stem cells. Sci. Rep. 8, 1-11 (2018).

21. Alhamami, M., Cheng, W., Lyu, Y., Allen, C., Zhang, X.-A. \& Cheng, H.-L. M. Manganese-porphyrin-enhanced MRI for the detection of cancer cells: A quantitative in vitro investigation with multiple clinical subtypes of breast cancer. PLoS One 13, 1-17 (2018).

22. Aime, S., Botta, M., Gianolio, E. \& Terreno, E. A p(O2)-Responsive MRI contrast agent based on the redox switch of manganese(II/III)-porphyrin complexes. Angew. Chemie Int. Ed. 39, 747-750 (2000).

23. Ren, Y., Sedgwick, A. C., Chen, J., Thiabaud, G., Chau, C. V., An, J., Arambula, J. F., He, X. P., Kim, J. S., Sessler, J. L., et al. Manganese(II) Texaphyrin: A Paramagnetic Photoacoustic Contrast Agent Activated by Near-IR Light. J. Am. Chem. Soc. 142, 16156$16160(2020)$.

24. Paul, G., Prado, Y., Dia, N., Rivière, E., Laurent, S., Roch, M., Vander Elst, L., Muller, R. 
N., Sancey, L., Perriat, P., et al. MnII-containing coordination nanoparticles as highly efficient T1 contrast agents for magnetic resonance imaging. Chem. Commun. 50, 67406743 (2014).

25. Ndiaye, D., Sy, M., Pallier, A., Même, S., de Silva, I., Lacerda, S., Nonat, A. M., Charbonnière, L. J. \& Toth, E. Unprecedented kinetic inertness for a Mn2+-bispidine chelate: a novel structural entry for Mn2+-based imaging agents. Angew. Chemie Int. Ed. (2020) doi:10.1002/anie.202003685.

26. Hamon, N., Roux, A., Beyler, M., Mulatier, J., Andraud, C., Nguyen, C., Maynadier, M., Bettache, N., Duperray, A., Grichine, A., et al. Pyclen based Ln(III) complexes as highly luminescent bioprobes for in vitro and in vivo one- and two-photon bioimaging applications. J. Am. Chem. Soc. (2020) doi:10.1021/jacs.0c03496.

27. Dioury, F., Sambou, S., Guéné, E., Sabatou, M., Ferroud, C., Guy, A. \& Port, M. Synthesis of a tricyclic tetraazatriacetic ligand for gadolinium(III) as potential contrast agent for MRI. Tetrahedron 63, 204-214 (2007).

28. Dioury, F., Ferroud, C., Guy, A. \& Port, M. Synthesis of an hexadentate tricyclic tetraazadiacetic ligand as precursor for MRI contrast enhancement agents. Tetrahedron 65, 7573-7579 (2009).

29. Drahoš, B., Kotek, J., Císařová, I., Hermann, P., Helm, L., Lukeš, I. \& Tóth, É. Mn2+Complexes with 12-Membered pyridine based macrocycles bearing carboxylate or phosphonate pendant arm: Crystallographic, thermodynamic, kinetic, redox, and 1H/17O relaxation studies. Inorg. Chem. 50, 12785-12801 (2011). 
30. Enel, M., Leygue, N., Saffon, N., Galaup, C. \& Picard, C. Facile Access to the 12Membered Macrocyclic Ligand PCTA and Its Derivatives with Carboxylate, Amide, and Phosphinate. European J. Org. Chem. 1765-1773 (2018) doi:10.1002/ejoc.201800066.

31. Devreux, M., Henoumont, C., Dioury, F., Stanicki, D., Boutry, S., Larbanoix, L., Ferroud, C., Muller, R. N. \& Laurent, S. Bimodal Probe for Magnetic Resonance Imaging and Photoacoustic Imaging Based on a PCTA-Derived Gadolinium(III) Complex and ZW8001. Eur. J. Inorg. Chem. 3354-3365 (2019) doi:10.1002/ejic.201900387.

32. Garda, Z., Molnár, E., Kálmán, F. K., Botár, R., Nagy, V., Baranyai, Z., Brücher, E., Kovács, Z., Tóth, I. \& Tircsó, G. Effect of the nature of donor atoms on the thermodynamic, kinetic and relaxation properties of Mn(II) complexes formed with some trisubstituted 12-membered macrocyclic ligands. Front. Chem. 6, 1-14 (2018).

33. Botár, R., Molnár, E., Trencsényi, G., Kiss, J., Kalman, F. K., Tircso, G., Botár, R., Molnár, E., Trencsényi, G., Kiss, J., et al. Stable and inert Mn ( II ) -based and pH responsive contrast agents Stable and inert Mn ( II ) -based and $\mathrm{pH}$ responsive contrast agents. J. Am. Chem. Soc. (2020).

34. Gale, E. M., Zhu, J. \& Caravan, P. Direct Measurement of the Mn(II) Hydration State in Metal Complexes and Metalloproteins through 17 O NMR Line Widths. J. Am. Chem. Soc. 135, 18600-18608 (2013).

35. Peters, J. A. \& Geraldes, C. F. G. C. A Semi-Empirical Method for the Estimation of the Hydration Number of Mn(II)-Complexes. Inorganics 6, 116 (2018).

36. Swift, T. J. \& Connick, R. E. NMR Relaxation Mechanisms of O17 in Aqueous Solutions 
of Paramagnetic Cations and the Lifetime of Water Molecules in the First Coordination Sphere. J. Chem. Phys. 37, 307 (1962).

37. Solomon, I. Relaxation Processes in a System of Two Spins. Phys. Rev. 99, 559-565 (1955).

38. Bloembergen, N. Proton Relaxation Times in Paramagnetic Solutions. J. Chem. Phys. 27, $572-573$ (1957).

39. Bloembergen, N. \& Morgan, L. O. Proton Relaxation Times in Paramagnetic Solutions. Effects of Electron Spin Relaxation. J. Chem. Phys. 34, 842 (1961).

40. Merbach, A. S., Helm, L. \& Toth, E. 4.3.5 Mn2+-based contrast agents. in The Chemistry of Contrast Agents in Medical Magnetic Resonance Imaging, 2nd Edition (eds. Merbach, A. S., Helm, L. \& Toth, E.) 179-183 (Wiley, 2013). doi:10.1002/9781118503652.

41. Laurent, S., Vander Elst, L., Henoumont, C. \& Muller, R. N. How to measure the transmetallation of a gadolinium complex. Contrast Media Mol. Imaging 5, 305-308 (2010).

42. Hare, D. J., New, E. J., De Jonge, M. D. \& McColl, G. Imaging metals in biology: Balancing sensitivity, selectivity and spatial resolution. Chem. Soc. Rev. 44, 5941-5958 (2015).

43. Laurent, S., Vander Elst, L., Copoix, F. \& Muller, R. N. Stability of MRI paramagnetic contrast media: A proton relaxometric protocol for transmetallation assessment. Invest. Radiol. 36, 115-122 (2001).

44. Wessells, K. R., Jorgensen, J. M., Hess, S. Y., Woodhouse, L. R., Peerson, J. M. \& 
Brown, K. H. Plasma Zinc Concentration Responds Rapidly to the Initiation and Discontinuation of Short-Term Zinc Supplementation in Healthy Men. J. Nutr. 140, 21282133 (2010).

45. Kim, M. G., Yoo, S. H., Chei, W. S., Lee, T. Y., Kim, H. M. \& Suh, J. Soluble artificial metalloproteases with broad substrate selectivity, high reactivity, and high thermal and chemical stabilities. J. Biol. Inorg. Chem. 15, 1023-1031 (2010).

46. Laurent, S., Vander Elst, L., Houzé, S., Guérit, N. \& Muller, R. N. Synthesis and characterization of various benzyl diethylenetriaminepentaacetic acids (dtpa) and their paramagnetic complexes, potential contrast agents for magnetic resonance imaging. Helv. Chim. Acta 83, 394-406 (2000).

47. Note: Chemicalize was used for prediction of pKas and speciation curves (December, 2019; https://chemicalize.com/, developed by ChemAxon): at highly acidic $\mathrm{pH}<1$, species charged +3 and +4 are predominant for compound $\mathbf{1 6 a}(85 \%$, and $15 \%$ respectively at $\mathrm{pH} 0.7$ ); at $\mathrm{pH} 4.5$ (chromatographied solution), species charged +1 , neutral, and charged +2 are predominant for compound $16 \mathrm{a}(73 \%, 15 \%$, and $12 \%$ respectively). 
Table of contents Graphic

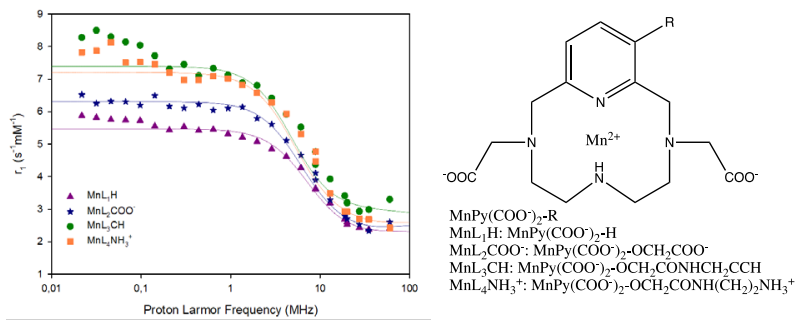

Table of contents synopsis

Step-by-step synthesis of manganese complexes based on the pyclen structure with a functionalized arm present on the pyridine moiety, as an alternative to gadolinium complexes as MRI contrast agents. This functionalized arm will allow the coupling of different molecules of interest for specific applications. A complete physicochemical characterization of the synthesized molecules is presented. 